\section{1．遅発性筋痛発症時の骨格筋と 脊髄後角の特徵}

○浦井 久子 ${ }^{1} 、$ 于田 宗弘 ${ }^{1} 、$ 岩田 晃 ${ }^{1} 、$ 上勝也 ${ }^{1}$ ( ${ }^{1}$ 大阪体育大学大学院 スポーツ科学研究科)

【緒言】慣れない運動や高強度のトレーニングを行った翌 日などに活動筋に痛みを感じることがある。光の痛みは遅 発性筋痛と呼ばれ、伸張性筋収縮後に筋を圧迫や収縮させ た時に発症し、自発痛は生じない。このような特徵から、 遅発性筋痛は機械的痛覚過敏の一種であると考えられてい る。これまでに実験動物に対する下り坂走のような生理的 条件下で起こる伸張性筋収縮後に遅発性筋痛が発症するか どうかは研究されていない。乥こで本研究はラットに下り 坂走を行わせ、筋痛 (機械的痛覚過敏) が起こっているか どうかを逃避行動テストと脊䯣後角に局在する2次求心性 ニューロンの活性化から検討した。さらに下り坂走後に骨 格筋で起こる变化と筋痛との関連性も検討することにより、 生理的条件下で起こる筋痛の侵害受容伝達系を明らかにす ることを目的とした。

【実験方法】実験動物には9週齢の Wistar 系雄ラットを用 い、ラットは下り傾斜角 17 度のトレッドミル走 (下り坂走) を行わせる群 (DH 群) と下り坂走により身体に出現する 種々の影響を確かめるため、平地走(傾斜なし)を行わせる 群 ( LV 群)に分けた。両群のトレッドミル走の条件は、 $25 \mathrm{~m} /$ 分のスピードで、1セット5分間の走運動を2分間の休 息を挟んで18セットの繰り返しとした。下り坂走6、12、24、 48、72、120時間後の下腿三頭筋における筋痛の評価はラ ンダルセリット法により行った（逃避行動テスト）。また、 別の群には脊骾後角ニューロンにおける c-Fos 蛋白を検出 するため、下腿三頭筋に30分間の圧刺激を与えてから脊骾 とヒラメ筋を摘出した (圧刺激実験)。脊䯣での c-Fos 陽 性ニューロンとヒラメ筋の ED1陽性マクロファージの局 在は免疫組織化学法により検討した。また、ウェスタンブ ロッティング法によりヒラメ筋における ED1陽性マクロ ファージの量的変化も調べた。

【結果と考察】ランダルセリット法による逃避行動テスト において、DH 群の逃避閾值は下り坂走 6 時間後に低下し 始め、12時間後には最低值を示し、弚の後回復する傾向を 示した。下腿三頭筋に対する圧刺激実験により脊骾後角表 層に現れる c-Fos 陽性ニューロン数は、下り坂走 12 時間後 に最も多く検出された。しかし、LV 群における c-Fos 陽 性ニューロン数の増加は認められなかった。一方、ヒラメ 筋筋線維には、下り坂走 48 時間後に顕著な筋線維の壊死が 認められ、また ED1陽性マクロファージは壞死した筋線 維内や筋線維間隙に観察されるとともに、弚の量的変化は 下り坂走24時間後に最高值を示した。これらの結果から、

下り坂走は下腿三頭筋に筋痛を発症させるとともに、光の ピークは12時間後になることが明らかとなった。さらにヒ ラメ筋内マクロファージ量や筋線維の壞死がピークを迎え る時期と筋痛がピークとなる時期にタイムラグが存在する ことも認められた。従って本研究結果は、遅発性筋痛は骨 格筋の組織的な損傷や炎症反応がピークとなるよりも先 立って発症することを示した。

Key Word

遅発性筋痛 機械的痛覚過敏 c - F o s 陽性ニューロン

\section{2.激運動がマウス海馬神経細胞に与える機能的影響の検討}

○住谷 和則 ${ }^{1}$ 、宮本 修 $^{2}$ 、山神 眞一 ${ }^{3}$ 、宮本 賢作 ${ }^{4}$ ( ${ }^{1}$ 香川大学 医学部 スポーツ生理学、 ${ }^{2}$ 倉敷芸術科学大 学 生命科学部 健康科学科、 ${ }^{3}$ 香川大学 教育学部 保 健体育、 ${ }^{4}$ 金沢大学 医学部 神経分布路形態形成学)

【目的】我々は、今までに長期的な激運動で産生される活 性酸素が、マウス海馬神経細胞に障害を与える可能性を示 してきた。今回は午の激運動による海馬神経細胞への影響 を機能的に明らかにするために、短期間による激運動前後 において記憶学習能力テストを行い、弚の変化を解析する。 とともに従来どおり海馬神経細胞の形態的变化も観察した。

【方法】雄マウス (体重30－35g) を、激運動群（週5回1 日1時間の速度 $30 \mathrm{~m} /$ 分のトレッドミル走)、全く運動しな い非運動群の2群に分けて1 週間の運動実験を行った。光 して、両群ともに海馬の機能的変化を解析するために、運 動前及び運動後に8方向放射性迷路を用いて記憶学習能力 テストを行った。光して運動後の記憶学習能力テスト終了 後に $4 \%$ パラホルムアルデヒドにて灌流固定を行い、脳を 摘出した。光の後凍結切片 $(20 \mu \mathrm{m})$ を作成して、 Hematoxylin-Eosin 染色 (HE 染色) を行い神経細胞障害 について確認した。さらに脂質酸化物のマーカーである 4-Hydroxynonenal (4-HNE) 抗体、免疫染色 (ABC 法) も行った。結果と考察】形態学的検討では、我々の先行 研究同樣に HE 染色では激運動群の海馬神経細胞 (CA1領 域) に障害が確認され、非運動群には変化がなかった。光 して4-HNE 抗体による免疫染色では、激運動群の海馬神 経細胞が強く染色されていた。よって、激運動による海馬 神経細胞障害の要因として、酸化ストレスが考えられる。 しかしながら、8方向放射性迷路を用いた記憶学習能力テ ストでは、激運動群と非運動群ともに、運動前よりも運動 後の方が有意差は認められなかったが、エラー数が減少し ており、テスト終了時間も少しではあるが短縮されていた。 さらに運動後におけるテストでは、エラ一数及びテスト終 了時間において両群間に有意な差は認められず、さらに海 馬神経細胞に障害が確認された激運動群の方が、運動前の 結果よりも若干ではあるが改善されていた。従って海馬に 酸化ストレスの影響を受け、機能的障害を受けると予想さ れた激運動群において、予想とは反して、明らかな機能的 障害は確認されなかった。今後、海馬神経細胞障害の要因 と光の機能的変化について詳細な検討が必要であることが 示唆された。(本研究は、文部科学省平成 18 年度科学研 究費補助金「若手研究(B)」課題番号177004945001による ものである。)

Key Word

海馬 酸化ストレス 8方向放射性迷路 
3. 発育期ラット海馬歯状回の神経新生率を促進する走運 動の至適時期と性ホルモン

○飯村 美歩 ${ }^{1}$ 、征矢 英昭 ${ }^{2}$

( ${ }^{1}$ 筑波大学大学院 体育研究科、 ${ }^{2}$ 筑波大学大学院 人間総 合科学研究科 運動生化学研究室)

【目的】運動が脑機能を改善し、認知機能やメンタルヘル スを改善しうる可能性が示唆されているが、発育期で光の 効果がどうなるかはいまだ決着をみていない。弚こで我々 の研究室では、発育期ラットを用いて走運動による神経新 生促進効果を検討した。運動期間は 4 週齢から開始する短 期間 (2週間) と長期間 (4週間)、運動強度は LT 強度前 後に設定した。光の結果、長期間で低強度の運動が海馬歯 状回 (dentate gyrus, DG) の神経新生をより促進させる という知見が得られた(榎枝，2005)。しかし、発育期でも 性成熟期に身体の発育か顕著に見られるように、運動によ る神経新生にも敏感な時期が存在しうるかもしれない。光 こで本研究では、発育期に走運動トレーニングにより惹起 される DG 神経新生促進効果を、運動時期 (発育前期 : 4 ～6週齢、発育急進期: 6 ～8週齢)の違いから、運動強度 (低 強度: LT 強度以下, 高強度: LT 強度以上) の影響を含め 検討することを目的とした。

【方法】Wistar 系雄性ラットを発育前期 (4 - 6週齢) 群 24 匹、発育急進期（6－8週齢）群24匹を用いた。各群を光れ 非運動群 $(0 \mathrm{~m} / \mathrm{min}, \mathrm{n}=8)$ 、低強度群 $(13.5 \mathrm{~m} / \mathrm{min}$, $\mathrm{n}=8)$ 、高強度群 $(25 \mathrm{~m} / \mathrm{min}, \mathrm{n}=8)$ に分け、1日30分の トレッドミル走運動を週6回、2週間課した。またサンプリ ング前6回のトレーニング時に、全てのラットに対し走運 動開始1時間前に $\mathrm{BrdU}(50 \mathrm{mg} / \mathrm{kgBW})$ を腹腔内投与した。 全トレーニング終了2日後に麻酔下で左心室から血液を採 取し、光の後還流固定を行い、脳をサンプリングした。摘 出した脳から DG を含む前額断切片を作成し、免疫組織科 学染色を施し、DGlmm²あたり新生神経細胞数を評価した。 また、血液からは神経新生に対し抑制的な作用をもたらす コルチコステロンロン濃度と成熟度を示す指標としてエス トロゲン $(\mathrm{E})$ ・テストステロン $(\mathrm{T})$ を測定した。

【結果】発育前期の新生神経細胞数は、非運動群に対し低 強度群で $14 \%$ 、高強度群で15％の増加を示したのに対し、 発育急進期では、非運動群に対し低強度群で $30 \%$ 、高強 度群で $47 \%$ の有意な増加を示した。しかし、いずれの時 期でも、新生神経細胞数の増加傾向に強度間の違いは認め られなかった。血漿コルチコステロン濃度は両時期のいず れの群間でも有意差はみられなかった。血中 $E$ 濃度は発育 前期〉発育急進期、T濃度は発育前期〈発育急進期の傾向 がみられた。

【考察】発育急進期群では低強度運動でも高い運動誘発性 の神経新生促進効果がみられたが、発育前期群ではみられ なかったことから、発育期において DG 可塑性の運動感受 性は発育急進期にある可能性があることが示唆された。成 獣ラットでも確認されている2 週間の走運動での神経新生 促進効果が、発育前期で確認されなかった理由については 不明だが、性成熟レベルの違いが一因として考えられる。 今後は、運動誘発性の神経新生促進効果に Tや $\mathrm{E}$ 受容体 が関与している可能性ついて、受容体拮抗薬や受容体の遺 伝子改変動物（アロマテースノックアウトマウスなど）を 用いて解析する予定である。

Key Word

神経新生 発育急進期 性ホルモン
4. 低強度トレッドミル走運動時のラット海馬血流量増加 の分子機構 : アストロサイトの代謝型グルタミン酸受 容体の関与

○西島 壮 ${ }^{1}$ 、征矢 英昭 ${ }^{1}$

( 筑波大学大学院 人間総合科学研究科 運動生化学研究室)

【目的】脳血流は神経活動を反映する間接的指標として， PETや NIRSなどの非侵襲的な血流測定装置を用いて広く 測定されているが，運動時の血流調節機構はほとんど検討 されていない．これに対して我々は，レーザードップラー 血流測定法 (LDF) とマイクロダイアリシス法を併用する ことにより，トレッドミル走運動時のラット海馬局所血流 量 (Hip-CBF) をリアルタイムにモニタリングするモデル を開発し、局所血流変化から海馬神経活動の調節機構を検 討している。局所脳血流量の調節には, 脳内の興奮性神経 伝達の中心を担うグルタミン酸作動性神経系が重要な役割 を担う.グルタミン酸受容体には、イオンチャネル型 (NMDA 型, AMPA 型, カイニン酸型) と代謝型 (mGluR1 - 8) の2 種類があり、イオンチャネル型受容体 のひとつである NMDA 受容体の活性化により一酸化室素

(NO) 合成が促進され、局所脳血流量を増加させる.昨 年我々も，トレッドミル走運動時の $\mathrm{Hip}-\mathrm{CBF}$ 調節に NMDA 受容体一NO シグナル経路が主要な役割を担うこ とを確認した(日本体力医学会大会，2005）。一方，近年 には Groupl mGluRs (mGluR1,5) も局所血流量の調節 に関与する可能性が報告された，乥こで本研究では，低強 度トレッドミル走運動時の Hip-CBF 調節に, Groupl mGluRs の関与があるかどうかを明らかにすることを目的 として実験を行った。【方法】12週齢 Wistar 系雄ラットを 用いた .ラットには 5 日間の走行学習を課し，トレッドミ ル走運動に馴化させた . 海馬背側 CA1領域に, Hip-CBF 測定用の LDF ガイドカニューラと，マイクロダイアリシ ス用のガイドカニューラを挿入した．Hip-CBFは，レー ザードップラー血流計 (FLO-Cl, OMEGAWAVE 社製) により測定した .ラットには低強度トレッドミル走運動 $(10 \mathrm{~m} / \mathrm{min} \times 80 \mathrm{~min})$ を課し，20分以降，1) Group1 mGluRs 阻害薬 (MPEP $1 \mathrm{mM}+$ CPCCOET $1 \mathrm{mM}$ ), 2) Vehicle (人工脳脊髄液) のいずれかを，60分間連続投与 した .【結果】低強度トレッドミル走運動により Hip-CBF は20 - 30\%増加し, Vehicle 投与は走運動時の Hip-CBF に影響を及ぼさなかった。一方，仮説に反して，Group1 mGluRs 阻害薬投与により走運動時の Hip-CBF は有意に増 加した . 阻害薬投与がラットの行動に影響を及ぼすことは なく ,ラットは安定したリズムで走運動を続けていた .【結 論】本研究は、走運動時の Hip-CBF が Groupl mGluRs を 介した抑制性の調節を受ける可能性を示唆する。これは、 運動時の Hip-CBF 調節は、NMDA 受容体を介した促進性 調節と，Groupl mGluRs を介した抑制性調節との動的平 衡によるとする新たな仮説を提起するものとして興味深い。 抑制性調節の詳細な機構は今のところ不明だが、一つの可 能性として麻薬関連物質として知られる、カンナビノイド による修飾効果が想定される。シナプス後部の Groupl mGluRs は内因性カンナビノイドを産生し， シナプスを逆 行性に作用して神経伝達物質の放出を抑制することが知ら れており、これにより結果的に血流が低下する可能性があ り、現在検討中である。

Key Word

海馬 局所脳血流量 代謝型グルタミン酸受容体 


\section{5. 運動強度の違いが胃の電気活動へ及ぼす影響について}

加藤 守匡 $^{1}$ 、征矢 英昭 $^{2}$

( ${ }^{1}$ 山形県立米沢女子短期大学 健康栄養学科、 ${ }^{2}$ 筑波大学 大学院人間総合科学研究科運動生化学研究室)

【背景】胃の運動機能は、低・中強度運動で促進するが、 高強度運動では逆に抑制されると報告されている。これら の報告は、胃管捰入法など、胃の残余量の解析から検討さ れたものが多く、被験者への負担も少なからず胃活動に影 響を与えると考えられる。胃電図法は非侵襲的に胃の電気 活動を測定することが可能であり、胃運動との関連も確認 され臨床的に利用されるようになってきている。我々は、 胃電図法を用いて中強度ペダリング運動後の胃の電気活動 を検討した結果、運動後に胃の電気活動は増大し、この増 大は迷走神経活動抑制下で生じることを確認している。目 的】本研究は幾つかの運動強度を設定し、運動強度の違い が胃の電気活動へ及ぼす影響について検討した。方法】 健常男性 8 名 (身長 $169.3 \pm 2.9 \mathrm{~cm}$ 、体重 $62.4 \pm 3.3 \mathrm{~kg}$ 、 BMI $21.9 \pm 1.3$ 、最大酸素攝取量 $41.1 \pm 2.9 \mathrm{ml} / \mathrm{kg} / \mathrm{min}$ ) を対象とした。3条件実施し、1) 安静20分・運動無し20分・ 回復20分、2）安静20分・負荷 $40 \% \mathrm{VO}_{2} \max 20$ 分の運動・回 復20分、3) 安静 20 分・負荷 $70 \% \mathrm{VO}_{2} \mathrm{max} 20$ 分の運動・回復 20分、1日1条件を実施した。実験間における自律神経、内 分泌反応の日内変動の影響を小さくするために3条件の測 定は同時刻に実施した。測定項目は胃電図による胃電気活 動、心電図、脳波であり、安静20分間と回復期20間を解析 対象とした。【結果】運動中の平均心拍数は、 $40 \% \mathrm{VO}_{2} \max$ は112.3 1.14 拍/分であり、 $70 \% \mathrm{VO}_{2} \max$ は142.4 2.119 拍 / 分であった。胃の電気活動は $40 \% \mathrm{VO}_{2} \max$ 、 $70 \% \mathrm{VO}_{2} \max$ 共に回復期において運動無し条件に比較し有 意な増大が認められた。胃の収縮周期の変動係数は、 $40 \% \dot{\mathrm{V}} \mathrm{O}_{2} \max 、 70 \% \dot{\mathrm{V}} \mathrm{O}_{2} \max$ 共に回復期において運動無し条 件に比較し有意な増大が認められた。心電図からの心拍変 動解析により得られた、副交感神経活動指標である HF 成 分は、 $40 \% \dot{\mathrm{VO}}_{2} \max 、 70 \% \dot{\mathrm{V}} \mathrm{O}_{2} \max$ 共に回復期において運動 無し条件に比較し有意な低下を示し、この低下は $70 \% \mathrm{VO}_{2} \max$ で低下が大きかった。 LH/HF 成分の比率は 回復期において運動無し条件に比較し有意な増加を示した。 脳波について、 $\alpha$ 波/ $\beta$ 波の比率は、運動前に比較し70 $\% \mathrm{VO}_{2} \max$ で有意な増大を示したが $40 \% \dot{\mathrm{VO}}_{2} \max$ では運 動前に比較し低下する傾向が示された。結論】低強度運 動は、運動後の脳の覚醒水準と交感神経活動を活性化させ、 食物の消化活動に適した状態を作り出すことが示された。 高強度運動では交感神経活動の強い活性化により胃の収縮 リズムの変動係数か増大し、食物の消化活動に適さない状 態か誘発されることが示された。今後は、内分泌や血流配 分などさらなる検討が必要である。(科学研究費補助金若 手 (B) (17700541) による研究の一部である)。
6. 右側罹患者ではうつ状態が強く出現する? 一整形外科外来患者を対象にした横断研究一

○山田 実 ${ }^{1}$ 平田 総一郎 ${ }^{2}$ 、小野 玲 $^{2}$

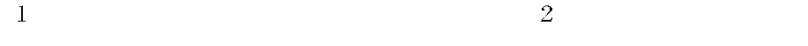
保健学科)

【はじめに】精神科以外の診療科に通院する患者では疾患 の背後にうつ状態を有していても、乥のことに気づかれる ことは少ない。これまでの報告によると整形外科外来に通 院する骨関節疾患患者であっても15～25\% はうつ状態にあ るとされている。うつは心の病、つまり脳機能との関連が 強く、うつ状態にあるものでは左前頭葉の機能低下と結び つけられることが多い。右側罹患の骨関節疾患患者では右 側からの正常な刺激量が減少、または negative な情報が 増大することから左側前頭葉の機能が低下する可能性があ る。脳血管障害の障害側半球別に検討した報告はあるもの の、末梢からの入力の変化によってうつ状態が惹起された という報告は皆無である。本研究では、右側罹患患者では うつ状態になりやすいという仮説検証を目的とする。【方 法】整形外科クリニックを受診された下肢骨関節疾患患者 135例を対象とした。年齢60.1歳、BMI 22.5であった。䍜 患側の内訳は右側罹患75例、左側60例であった。うつ状態 の評価としては、Self-rating Depression Scale (SDS) を 用いた。日常生活動作レベルには Health assessment questionnaireを用いた。疼痛の評価はVisual analog scale (VAS) を用いた。光の他、よく状態の基礎疾患となり うる高血圧、高脂血症、糖尿病の有無、職業、平素のス卜 レスの有無を調査した。統計解析には重回帰分析（強制投 入法) を用いて、従属変数に罹患側、HAQ、VAS、年齢、 高血圧、高脂血症、糖尿病、職業、平素のストレスを投入 し、うつ状態に影響を及ぼす因子を検討した。【結果】全 対象者のSDSは42.4であり、うつ状態とされる SDS50以 上のものは30例 (22.2\%)、ボーダーラインとされる SDS40 以上のものを含めると87例 (64.5\%) であった。右側罹患 患者の DSD は 46.3 、左側患者では37.6で有意な差を認め た ( $<<.001)$ 。重回帰分析の結果、 R 2 值 $=.406 、 \mathrm{p}<.0001$ であり、有意であった因子は罹患側 $(\beta=-.517 、 \mathrm{p}<.0001) 、$ $\operatorname{VAS}(\beta=.218 、 p=.003)$ 、平素のストレス $(\beta=-.174$ 、 $\mathrm{p}=.018)$ であつた。【考察】最も強くうつ状態に影響を及 ぼす因子は右側罹患であることだった。このことから、右 側からの刺激入力の变化が左前頭葉の機能低下を招き、う つ状態に至らせた可能性が示唆された。本研究で、右側䍜 患患者のうつ状態に至るメカニズムを論じるには限界があ り、今後の課題としたい。しかしながらこのことは臨床上、 非常に有用な情報であり、特に右側䍜患患者の場合には精 神面に対するアプローチも必要である可能性が高い。

Key Word

うつ状態 骨関節疾患 右側罹患 


\section{7. 振動刺激により誘発される運動単位活動の特徵}

○加茂 美冬

( ${ }^{1}$ 日本女子体育大学 体育学部 運動科学科)

最大下一定筋力発揮において, 一定筋力発揮開始時から数 十秒-数分の間, 運動単位の放電間隔は延長する(加茂と森 本1990, Kamo and Morimoto 2001, Kamo 2002). この放 電間隔延長は, 力の融合程度を低下させ筋単位不完全強縮 張力の増強を防ぐことに貢献している (Kamo and Morimoto 2005) . しかしながら, 放電間隔を延長に導くメカニズ ムは明らかではない，本報告では，随意筋力発揮時の放電 間隔延長の仕組みを理解することを目的として，振動刺激 により誘発される運動単位活動および振動刺激が随意筋力 発揮時の運動単位活動に及ぼす効果について再検討した . 膝関節角度 90 度の条件において内側広筋の単一運動単位活 動を観察した . 樣々な振動刺激条件による同一単一運動単 位活動の観察を可能とするために活動電位の導出には表面 電極法を用いた，光の結果，振動刺激により誘発された運 動単位活動の放電間隔変化は随意活動時と類似する場合が 観られた . また , 随意一定筋力発揮中に振動刺激を加えた とき, 運動単位放電間隔は短縮した。

\section{8. 加齢に伴う筋紡鍾 la 群感覚神経の形態変化}

○金 祉希 ${ }^{1}$ 、鈴木 秀次 ${ }^{2}$ 、神田 健郎 ${ }^{3}$

( ${ }^{1}$ 国立リハビリテーションセンター研究所 運動機能系障 害研究部、2 早稲田大学人間科学学術院、3新宿鍼负柔整専 門学校)

【はじめに】我々は老齢ラットの腓腹筋の筋紡鍾から Ia 群の単一神経活動を記録し、加齢に伴い動的感度や伝導速 度が低下していることを明らかにした (Miwa et al., 1995)。 また ramp-and-hold 伸張刺激に対し、老齡ラットにおい て II 群神経のような発射パターンを示すユニットが多 かったことから、加齢に伴い Ia 群神経の何らかの変性を 起こすのか、光れとも Ia 群神経の数が減るのか、この二 つの可能性が考えられる。【目的】本研究は、形態学的手 法を用いて筋紡錘の感覚神経、とりわけIa 群感覚神経の 形態の加齢変化を調べることを目的とした。方法】実験は、 Fishier344/DuCrj 雄性ラットを用い、Young (8〜10ヶ月 齢), Middle-aged (20.5 22ヶ月齢), Aged (28〜30ケ月 齢)の三つのグループの腓腹筋で調べられた。まず、腓腹 筋を摘出し、固定した後、硝酸銀染色を行った。乥れから 兴の試料を筋線維に沿って細く裂いて、単一筋紡錘を取り 出した。光して取り出された単一筋紡鍾をスライドグラス に挟んで押しつぶした後、光学顕微鏡レベルで観察した。 写真撮影後、パソコンに取り込み、ソフトウェア (ImageJ 1.34s）を使って筋紡鍾近くでの Ia 群及び II 群神経の軸索 の直径、筋紡鍾の錘内筋線維上での第一感覚終末の分布範 囲や transverse bands の数、第一感覚終末の形態を定量化 した。【結果および考察】I a 群神経の軸索の直径は、

Youngや Middle-aged グループに比べて Aged グループで 有意に細くなっていることがわかった $(\mathrm{P}\langle 0.01)$ 。この 結果は、加齢に伴い I a 群感覚神経の伝導速度が遅くなる という機能的変化を裏付けるものとなった。また筋紡錘の 錘内筋線維上での第一感覚終末の分布範囲や transverse bands の数も Youngや Middle-aged グループに比べて Aged グループでは有意に小さかった $(\mathrm{P}\langle 0.01)$ 。光して Youngや Middle-aged グループのほとんどの筋紡錘では、 第一感覚終末が螺旋状であったことに比べて、Aged グ ループでは、螺旋状の筋紡錘が少なく、第一感覚終末の形 態が变成したタイプの筋紡錘が多く分布されていることが 明らかになった。これらの結果から、加齢に伴い Ia 群感 覚神経線維の数は減らないが、形態的に変成を起こし、 Ia 群の発射パターンに影響しているとことが示唆された。 したがって、本研究で明らかになった加齢伴う筋紡錘 Ia 群感覚神経の形態の選択的变化は、筋紡錘の機能的变化と 関係があると考えられた。

Key Word

筋紡鍾 Ia 群感覚神経 加齢变化 
9. 筋交感神経活動の増強手技におけるヒトのヒラメ筋伸 張反射および $\mathrm{H} 反$ 射応答

○上林 清孝 ${ }^{1}$ 、尾方 寿好 ${ }^{1}$ 、赤居 正美 ${ }^{1}$ 、中澤 公孝 ${ }^{1}$ ( ${ }^{1}$ 国立身体障害者リハビリテーションセンター 研究所)

【目的】安静時と比較して, 筋交感神経活動が増加する持 続的なハンドグリップ時や暗算実施時において，I a 群感 覚神経の発火増加やアキレス腱タップによる腱反射の元進 が近年報告されている。また，中枢性疾患の患者において， 精神的な不安や緊張, 膀胱の充満などの因子によって痙縮 か強く現れるように，臨床的な観察からも反射進に対し て自律神経系との関連性が推察されている。これらは, 交 感神経活動の増加が筋紡錘感受性の増加に関連しているこ とを示唆するかもしれない。本研究では, 筋交感神経活動 の六進が知られている樣々な課題実施がヒラメ筋の機械的 な筋伸張による伸張反射と末梢神経の電気刺激による $\mathrm{H}$ 反射に及ぼす影響を調へ，交感神経活動による伸張反射六 進のメカニズムを探ることを目的とした。【方法】被験者 は健常成人 16 名で, 座位姿勢にて心拍数, 血圧, 右下肢の ヒラメ筋および前脛骨筋から表面筋電図を記録した。筋交 感神経活動を増加する課題として，暗算，最大筋力の $30 \%$ 強度で握力保持, 握力保持の終了直後に上腕部での阻血，

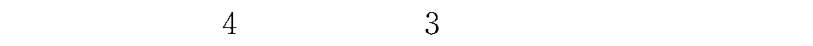
時に, 伸張反射と $\mathrm{H}$ 反射を 5 秒間隔で交互に誘発した。伸 張反射は, 足関節角度 $90^{\circ}$ から $250^{\circ} / \mathrm{s}$ の速度で $10^{\circ}$ の機 械的な背屈によって誘発し, 短潜時でみられるピーク振幅 で反射応答を評価した。 $\mathrm{H}$ 反射は，最大 $\mathrm{M}$ 波振幅の $10 \%$ に相当する $\mathrm{M}$ 波を誘発する刺激強度によって測定した。 さらに追加実験として，H 反射振幅の大きさを伸張反射 振幅に対応させるため，M 波閾值下の弱い刺激強度によ る $\mathrm{H}$ 反射を用いて，2つの異なつた電気刺激強度（運動閾 值上と運動閾值下) による測定も行った。【結果】心拍数は, 暗算や握力保時で安静と比較して有意に増加した。血圧は 安静時に対してすべての課題で増加を示し, 握力, 阻血, 冷刺激で有意な上昇であった。反射応答に関して, 伸張反 射応答では安静時に比べて全課題実施時で有意に増加した。 反射穴進の度合いは, 血圧の増加と同樣の傾向を示した。 一方, $\mathrm{H}$ 反射振幅は課題実施時に増加傾向を示すものの， 安静時と比較しては有意な変化ではなかった。反射サイズ の小さい, 閾值下の刺激強度の場合でも， $\mathrm{H}$ 反射の大き さは安静時と比較して課題実施時にわずかな増加を示すの みであった。考察】課題実施時での心拍数や血圧の変化 パターンは, 微小神経電図による直接的な記録から筋交感 神経活動の増加を報告した先行研究と類似しており，本実 験においても筋交感神経活動の増加が推察された。このよ うな状況下で，伸張反射でのみ反射の六進が観察された。 伸張反射と $\mathrm{H}$ 反射での反射六進の相違から，課題時での 伸張反射の増加は $\alpha$ 運動ニューロンの興奮性増加やシナプ ス前抑制における脱抑制などの要因よりも筋紡錘の感受性 における変化によるものと示唆された。このような筋交感 神経活動による反射の六進は, 交感神経活動が高まるよう なスポーツ場面での緊張状態において，運動制御に影響を 与えているかもしれない。

Key Word

伸張反射 $\mathrm{H}$ 反射 筋電図

\section{0. 運動終了後の心拍数減衰と呼吸変動の関係}

○田島 多恵子 1 、只野 千茅、下瀬 良太 ${ }^{1}$ 、与那 正 栄 2 、内藤 祐子 $^{3}$ 、関 博之 ${ }^{4}$ 、室 増男 $^{1}$

( ${ }^{1}$ 東邦大学医学部、 ${ }^{2}$ 東京薬科大学薬学部、 ${ }^{3}$ 国士舘大学体 育学部、4 新潟経営大学情報学部)

【目的】運動終了直後の心拍数 (HR) の急峻な減衰は, 背景にある交感神経活動状態によって副交感神経の働きが 影響を受けた結果生じる。光して，この副交感神経の再興 奮の強さは，時定数 (TC) によって評価できることが知 られている。この回復 HR における急峻相の減衰要因が, 随意的無呼吸 (VNB) に関連しているか検討した。方法】 被験者は，健常成人6名 (平均年齢 $43.8 \pm 10.97$ 歳) を用い た。自転車エルゴメータによる被験者の anaerobic threshold (AT) を決定した後, 別日に ATレベルの自転 車運動を行った。測定項目は呼吸曲線と呼吸のボリューム， 乥して心電図 (CM5) を経時的に計測した。プロトコール はサドルでの座位姿勢をとり, 安静5分間の後, 10 秒間の VNB を3回行った。このVNBのタイミングは, 呼気への 移行相で呼吸を停止するように指示した。続いて，休息を 挟んで5分間の運動を行い, 運動終了と同時にVNB 66秒 間行った。この時，運動終了のタイミングを呼気の移行相 に合わせるよう指示した。弚の後，回復を5分間行った。 さらにコントロール (CON) として再度, 5 分間の運動の後， 自然な呼吸のまま，5分間の回復を計測した。VNBによ る HR の減衰は, 平均7秒間の急峻な変化とした。TC は 運動終了後, 30秒間の回復 HR から推定した。また心拍変 動 (coefficient variability of $R-R$ interval : $\mathrm{CV}_{R R}$ ) と呼吸 変動 (coefficient variability of respiratory cycle: $\mathrm{CV}_{\text {Resp }}$ ) を算出した。【結果と考察】 $C V_{R R}$ と $C V_{R e s p}$ の相関は, 安静が $r=0.954$, 運動時が $r=0.796$ を示し, 高い相関が見 られたことから, 生理学的に呼吸性洞性不整脈の存在が確 認された。さらにHRの減衰は, 安静時が平均-1.247

$(\mathrm{HR} / \mathrm{sec})$, 運動後が平均-4.083 ( HR/ $/ \mathrm{sec})$ を示し, 運動 後に安静時の弚れよりも強く出現した。回復 HR の TCは, CON が80.02sec, 運動後のVNB が90.13sec であり， VNB による回復の速さへの影響はみられなかった。これ はVNBによる反射的なHR の減衰が数秒間起こり，光の後， ネガティブフィードバックにより HR の上昇が起こるため であると考えられた。光して運動後のVNB によるHR の 減衰と TCの間に相関がみられなかったことから，運動後 の VNB による HR の減衰は, 副交感神経活動の再興奮の 強さとは無関係であることが示唆された。また安静時の $\mathrm{VNB}$ によるHR の減衰は, $\mathrm{CV}_{\mathrm{RR}}$ と $\mathrm{CV}_{\mathrm{Resp}}$ に各 $\mathrm{r}=0.812$ ， $\mathrm{r}=0.7$ の相関がみられたことから, $\mathrm{CV}_{\mathrm{RR}}$ と $\mathrm{CV}_{\mathrm{Resp}}$ の大き さに，血管運動中枢への影響が強く，心藏抑制中枢への影 響が反射的な抑制に及んでいるものと思われた。【結論】 運動終了後に随意的無呼吸を行うことによって，急峻な心 拍数の減衰か加速した。この心拍数の減衰は安静時よりも 運動後に大きく出現した。ところか随意的無呼吸による心 拍数減衰率は, 回復心拍数のタイムコンスタントとは相関 しなかった。

Key Word

呼吸変動 心拍数減衰 副交感神経 


\section{1. 萎縮筋の錘内筋線維における NT-3と TrkC 発現の特徵}

○廣瀬 立朗 ${ }^{1}$ 、岩田 晃 ${ }^{2} 、$ 浦井 久子 ${ }^{2} 、$ 宇田 宗弘 ${ }^{2} 、$ 石道 峰典 ${ }^{2}$ 、上 勝也 ${ }^{2}$

$\left({ }^{1}\right.$ 日本体育大学 運動生理学研究室、 ${ }^{2}$ 大阪体育大学大学 院スポーツ科学研究科)

【緒言】運動が神経機能の維持や改善に有効であるという ことは良く知られているが、兴のメカニズムは充分に解明 されていない。一般的に神経栄養因子は神経系の構造と機 能の改善に影響を及ぼすことか認められおり、しかも運動 により海馬などでは神経栄養因子の発現が促される (Neeper et al.,1995)。骨格筋における運動神経や固有受 容器などに影響を及ぼす神経栄養因子としては、Neurotrophin-3 (NT-3)やBDNF が知られている。これらの因子 の骨格筋における発現は走運動により増加することから、 神経系に何らかの影響を及ぼしていると考えられている

(Gomez-Pinilla et al., 2001)。乥こで昨年の本学会にお いて、私達は NT-3と光の受容体である TrkC がラット骨 格筋の錘内筋線維に発現し、光れらの発現部位は筋萎縮モ デルである尾部懸垂により変化しないことを報告した。 本研究は、尾部懸垂がラットヒラメ筋の NT-3と TrkCの 発現量に及ぼす影響について検討することを目的とした。

【実験方法】実験動物には5週齢のウィスター系雄ラット、 18匹を用いた。ラットは尾部懸垂1週間群 $\left(1 \mathrm{wk}^{-}\right.$-sus ； $\left.\mathrm{n}=6\right)$ 、 尾部懸垂2週間群 (2wk-sus； n=6)、コントロール群 ( con ; n=6) に分けた。各実験群のラットからヒラメ筋 を摘出し、ウエスタン・ブロッティング法により NT-3と TrkCの発現量を検討した。【結果と考察】NT-3は 1 wk-susにおいて発現量が低下する傾向を示し、2wk-sus ではコントロールレベルにまで回復した。また、TrkCの 発現量は1wk-sus で統計的に有意に減少し、2wk-sus でコ ントロールレベルに回復した。これらの結果を昨年の研究 結果とあわせて考察すると、尾部懸垂1週間目における NT-3と TrkCの発現の減少は、不活動に対する筋紡鍾の 機能変化に重要な役割を演じると考えられる。また尾部懸 垂2週間目では筋紡鍾における NT-3と TrkCの発現が回復 し、NT-3のレセプターである TrkCの発現量の増加が示 された。従って、筋紡錘は NT-3を受け取りやすくなり、 ぞの結果 NT-3と TrkCの結合は PIBK/AKT, MAPK, PLC $\gamma / \mathrm{IP3}$ 経路の活性化を促すことで神経細胞の成長や機能維 持を促進すると考えられる。尾部懸垂2週間目における NT-3と TrkC 発現の増加は、筋紡錘機能を回復させるこ とで新しい環境への適応反応の一つとして誘導される可能 性が示唆された。

Key Word 尾部懸垂 筋紡錘 神経栄養因子

\section{2. ゲーム反応時間の時系列分析による認知能力評価}

○永田 戬 ${ }^{1}$ 横山 祐樹 ${ }^{1}$ 、桜田 惣太郎 ${ }^{1}$ 、小川 耕平 $^{1}$ ( ${ }^{1}$ 富山伝統医学センター 運動生理)

【目的】認知能力の定量的な評価法は、認知症との関連で 急務な課題である。また学童の認知能力は、加齢とともに 未発達で、青壮年者よりも劣ると思われる。しかし、乥の 認知能力の定量的な評価法と加齡的な比較発表は少ない。 今回カード・ゲーム CogHealth ソフト2種目を取り上げ、 パソコン上でトランプゲームを行い、判断能力、短期記憶、 一過性の精神的な飽きなどを統合した認知能力の評価法を 提示するのを目的とした。【方法】健康な学童群 ( $P G$, 平 均年齢 8.3 歳) 15 人と青壮年者群 $(\mathrm{AG}$, 平均年齢 39.3 歳) 19人を被験者として、CogHealth 課題の内、単純記憶課題 (M) と広域注意・動的課題 (D) の2種目をとりあげて 両群の成績を比較した。第一の M 課題は、CRT 上の30枚 のカードが順次裏から表に返した時に、前のカードと同一 か否かを判断する課題である。二番目の D 課題は、5枚の カードが上下方向に不規則に動き、いずれかのカードが上 下端に位置する白線に触れた時にすばやく応答するゲーム である。いずれも課題別の反応時間を測定し、さらに経時 的な反応時間の変化を分析した。また反応時間と反応速度 間のナイキスト線図を描き、反応周波数(f) と線図内の軌 跡長 (LD)を記録した。時系列分析法には MemCalc の周波 数分析法を適用し、反応時間振幅スペクトル波形を描き、 べきスペクトル回帰式 $(1 / \mathrm{f})$ の勾配 $(\beta)$ と $0.001 \mathrm{~Hz}$ か ら $0.5 \mathrm{~Hz}$ までの全パワー密度面積 (TPS) を計算した。 $\mathrm{D}$ 課題別に、両群の $\beta$ 值と TPS 值並びに $\mathrm{f}$ 值と LD 值の变 化をまとめ、高次脳神経系の活動状態としての認知能力を 比較した。【結果と考察】 PG の M と D 課題の合計反応時 間 (カッコ内は $\mathrm{AG}$ の值) は、平均 $846 \mathrm{msec}(475 \mathrm{msec})$ と $730 \mathrm{msec}(438 \mathrm{msec})$ を示し、瞬時的な記憶力と動的な判断 力と集中力が比較され、学童の低值が得られた。両群の課 題実施中の反応時間の分散 (一貫性) と反応周波数帯域に ついての有意差は見られなかった。PG のD課題の正確性 は、平均 $83.0 \%$ (92.5\%)を示し、 $\mathrm{M}$ 課題の反応速度は平均 $91.5 \mathrm{~mm} / \mathrm{msec} \quad(102.5 \mathrm{~mm} / \mathrm{msec})$ を示した。しかし、ナイ キスト線図 (時間と速度の関係) 内の移動周波数は、D 課題において平均 $0.92 \mathrm{~Hz}(1.06 \mathrm{~Hz})$ を示し有意な差が見ら れたが、M課題ではほぼ同じ平均 $0.97 \mathrm{~Hz}$ を示して両群間 に有意な差はなかった。 $\mathrm{D}$ 課題のスペクトル波形内の $\beta$ 值 (傾斜) と TPS 值 (全面積) は、平均-7.4 (-4.4)勾配 と平均 $0.2(0.7) \mathrm{mV} \cdot \mathrm{Hz}$ 面積を示した。これらのデータ から、トランプゲームに応答した作業時間の時系列分析に おいて、AGの一時的な抗精神的疲労・抗飽和状態や動的 な注意力・広範囲にわたる動的な認知・判断力などの高值 が算出され、PG と比較して優れた能力を現した。さら にゲーム反応時間変化 (リズム) のスペクトル分析によっ $\tau$ 、LD , $\beta$, TPS 等の評価関数が得られ、認知能力は統 合的に客観的に評価された。学童は青壮年者よりも発達上 低い統合的な認知能力を示し、同時に CogHealth ゲーム課 題の反応時間・時系列分析手法よって、認知能力の妥当な 評価関数と加齢による能力発達差も検証された。認知能力 の評価には、ゲームなどの反応時間の作業リズムを分析し て、短期記憶、一過性の飽き、動的な集中力、正確性に関 する尺度を算出する必要があるだろう。

Key Word

認知能力 時系列分析 反応時間 


\section{3.ラジオ体操が脳内の認知機能に及ぼす影響}

○西川 佳克 ${ }^{1}$ 、西平 賀昭 ${ }^{1}$ 、東浦 拓郎 ${ }^{1}$ 、紙上 敬太 ${ }^{1}$ 、 金 勝烈 ${ }^{1}$

( ${ }^{1}$ 筑波大学大学院 人間総合科学研究科 体育科学専攻運 動生理学研究室)

【目的】ラジオ体操は, 国民の健康維持増進を目的に現在 でも家庭や学校, 職場や地域などでも実施され, 老若男女 を問わず容易に行うことのできる体操として親しまれてい る.さらに，毎日テレビとラジオで放送され，日常生活の 中でも継続的にできる体操であると考えられる．しかしな がら，ラジオ体操が心身の制御に深く関与する中枢神経系 に及ぼす影響に関しては検討されていない，乥こで，本研 究では反応時間 (RT) と事象関連電位のP3を用いてラジ 才体操が認知機能に及ぼす影響を検討した。【方法】参加 者は, 53〜74歳の健常成人20名（男性10名，女性10名）で， ラジオ体操前後にP3を誘発する選択反応課題を実施した.

【結果】認知パフォーマンスは, ラジオ体操後で有意に向 上した (エラー率の低下, RT の短縮) .さらに, P3振幅 は ,ラジオ体操後で有意に増大した。【結論】このことから， ラジオ体操実施直後には, 脳内の認知機能が促進すること が示唆された .

\section{4. 精神疲労に伴う脳機能低下に及ぼす香りの効果}

○加藤 雄一郎 ${ }^{1}$ 、遠藤 博史 $^{1}$

( ${ }^{1}$ 産業技術総合研究所)

【目的】自動車運転のような認知的活動を長時間継続する と精神疲労が生じる。精神疲労は，反応時間の遅延やエラー の増大といったパフォーマンスの劣化を引き起こすことが 知られている。先行研究において我々は, 精神疲労に伴い 反応抑制系の処理が遅延し, 誤反応のモニタリング機能が 低下することを報告し，これらが前帯状回 (ACC) の機能 的低下に関連していることを示唆した。光こで本研究では， 香りの持つ疲労低減効果によって ACC が活性化すると仮 説し, 香りが精神疲労に伴うパフォーマンスの劣化を抑制 するのかどうかについて検討することを目的とした。光こ で，Go/NoGo 反応課題を 1 時間遂行中の事象関連電位を 計測し，「香り」条件と「コントロール」条件とで群間の 比較を行った。【方法】被験者は, 健常成人 28 名 (男性 18 名, 女性 10 名) であり, 無作為に二オイ群 ( $\mathrm{n}=14)$ と コントロール群 $(\mathrm{n}=14)$ に分けた。被験者は，視覚刺激 に対する Go/NoGo 反応時間課題を 1 時間継続した (1440 試行)。視覚刺激は注視点の左右にランダムに二 (Go 刺激) または○ (NoGo 刺激) が呈示された。被験者には，左の Go 刺激に対しては左手，右の Go 刺激に対しては右手で ボタンを押すように，NoGo 刺激に対しては反応をしない ように指示した。刺激の呈示確率は $80 / 20$ であった。二 オイ群には, メントール, 緑の香り , シトラスの 3 種類 の匂いが間欠的に放出され，コントロール群には空気のみ が放出された。脳波は $\mathrm{Fz}, \mathrm{Cz}, \mathrm{Pz}, \mathrm{C} 3$ '，C4’から計測 した。事象関連電位は，反応抑制に関する陰性成分 (NoGo N2), 反応準備に関わる側方性準備電位 (LRP), エラーに関する陰性成分 $(\mathrm{Ne} / \mathrm{ERN})$ を計測した。【結果 と考察】反応時間は, 課題遂行の時間経過と群間の違いに よる交互作用が認められた。二オイ群の反応時間に有意差 はなかったが $(290,290,290 \mathrm{~ms})$ ，コントロール群の反 応時間は有意に遅延した $(286297,304 \mathrm{~ms})$ 。誤反応率は 時間経過と伴に有意に増加したが $(6.9,8.7,8.7 \%)$, 群 間に有意差は認められなかった。NoGo-Go N2 振幅は， $\mathrm{Fz}$ において二オイ群の方が有意に大きく， $\mathrm{C} z, \mathrm{Pz}$ におい て時間経過とともに低下することが認められた。この振幅 の低下は，二才イ群で顕著な傾向を示した。 Stimulus-locked LRP は振幅に有意差は認められなかった が，NoGo 刺激における潜時は，二オイ群の方が有意に遅 く，コントロール群は時間経過と伴に遅延することが認め られた。したがって，二オイ群では，反応抑制の活動を減 衰させることで反応準備の処理資源を維持する方略的な変 容が起きている可能性が考えられた。しかし，これが香り による効果なのか，群間の違いによるものなのかは明らか ではない。Response-locked LRP と Ne/ERN は，課題遂 行の時間経過に伴い振幅が有意に低下することが認められ たが , 群間に有意差は認められなかった。つまり，反応実 行系の活動強度, 誤反応のモニタリング機能の低下に対す る香りの効果は確認されなかった。これらの結果から，香 りは, 反応時間の遅延を抑制させる効果を持つことが示唆 されたが，ACC を活性化し得るかどうかは明確にできな かった。今後さらに検討する必要がある。(本研究は日産 自動車株式会社による助成を受けて行われた。)

Key Word

精神疲労 香り 事象関連電位
ラジオ体操 選択反応課題 認知機能 
15. 脳内セロトニンの食欲抑制効果とその機序に関する検討

○篠崎 智一 ${ }^{1}$ 、木村 真規 ${ }^{1}$ 、柴崎 敏昭 ${ }^{1}$

( ${ }^{1}$ 共立薬科大学 薬物治療学講座)

【目的】肥満は糖尿病、高血圧、高脂血症が個人において 併発するメタボリックシンドロームを形成する主要因とし て社会的問題になっている。肥満を改善する方法として食 事療法および運動療法が一般的に行われるが、両者ともに 一時的な効果は認められるものの行動の改善を継続するこ とは難しく、弚の多くの者は食欲の亢進により元の体重に 戻ってしまう。体重減少時の食欲の六進は、視床下部領域 の neuropeptide Y (NPY)の増加により惹起されることか ら、肥満を改善するにはNPY の増加を抑制するような介 入が適していると考えられる。近年、肥満症および捸食障 害の治療や研究において選択的セロトニン再取り込み阻害 薬やセロトニンーノルアドレナリン再取り込み阻害薬が使 用され、用量依存的な体重の減少と減量後の体重維持に有 効である可能性が示されたことから、セロトニン $(5-H T)$ の食欲調節作用に注目が集まっている。5-HT の食欲抑制 効果の特徵として炭水化物摂取量を低下させることが知ら れている。一方、NPY は炭水化物摂取量を増加させるこ とから5-HT はNPY の発現量を抑制することで食欲を低 下させている可能性が示唆されるが弚の詳細は明らかに なっていない。光こで本研究では選択的セロトニン再取り 込み阻害薬であるフルボキサミン (Flu)を用い、5-HT の 食欲調節効果と中枢性摂食調節因子である NPY との関係 について検討を行った。【方法】雄性のWistar ラット、過 食性肥満モデル OLETF ラットを乥れ光れ F1u 100 $\mathrm{mg} / \mathrm{kg} / \mathrm{day}$ 投与群と水道水投与対照群に分け 10 日間の療 法を行った。Flu および水道水は1日1回経口投与、摂飭お よび摂水は自由摂取として体重および攝飭量の変化につい て観察を行った。NPY の評価は視床下部領域の蛍光免疫 組織化学染色を行い、蛍光強度の強さを NIH image で定 量した。【結果および考察】Wistar ラットでは投与開始初 期において Flu 投与による捸餌量の減少傾向が観察された が、投与開始 4 日目頃から水道水投与対照群と同程度の攝 餌量まで回復し、療法終了時では体重の低下と摂餌量の減 少は観察されなかった。一方、OLETF ラットではFlu 投 与群において投与初日から摂餌量の低下がみられ、この効 果は療法期間中に継続して観察された。さらに摂飯量の低 下に伴う体重の減少も認められ、5-HT による捸食抑制効 果が示唆された。視床下部のNPY を測定したところ、 Flu 投与群では NPY の低下が弓状核において観察され、 5-HTはNPY の抑制を介して食欲を抑制した可能性が示 唆された。

\section{6. 運動経験の違いによる海馬構造と抑うつ度の関係}

○権藤 雄一 ${ }^{1}$ 、泉水 宏臣 ${ }^{2}$ 、藤本 敏彦 ${ }^{3}$ 、永松 俊哉 ${ }^{2} 、$ 千葉 登 ${ }^{4}$ 、小川 静香 ${ }^{4}$ 、竹倉 宏明 ${ }^{5}$

( ${ }^{1}$ 仙台リゾートアンドスポーツ専門学校、鹿屋体育大学 大学院、 ${ }^{2}$ 明治安田厚生事業団 体力医学研究所、 ${ }^{3}$ 東北大 学 高等教育開発推進センター、 ${ }^{4}$ 東北大学大学院 医学 系研究科 運動学分野、5鹿屋体育大学 スポーツパフォー マンス系)

【目的】現代社会では、樣々な精神疾患や過多なストレス など、精神的健康の悪化が社会的問題になっている。乥ん な中、運動が精神的健康に寄与することが多くの研究で報 告されているが、弚のメカニズムの詳細は明らかになって いない。近年、動物実験では、運動が海馬の細胞増殖を促 進し、抑うつを改善することが報告されている。また、ヒ 卜において、海馬体積の減少が樣々な精神疾患と関係して いることも報告されている。しかし、ヒトによる運動によ る海馬への影響と抑うつ度との関係は明らかになっていな い。光こで本研究では、運動経験の豊富な学生と運動経験 の乏しい学生を対象とし、脳 MR 画像を用いて海馬構造を 比較し、抑うつ度との関係を調べた。

【方法】被験者は、右利きの非喫煙者である健康な男子学 生を対象とし、運動経験の豊富な学生を Athlete 群 $(\mathrm{n}=22$ 、 $21.8 \pm 2.2$ 歳)、運動経験の乏しい学生を Sedentary 群 ( $\mathrm{n}=20$ 、 $22.2 \pm 2.1$ 歳) とした。測定項目は、身長、体重、過去の 運動歴、推定最大酸素攝取量であり、脳画像処理および解 析は、optimized voxel-based morphometry 法により行った。 抑うつ度の測定は、CES-D scale、K10うつ尺度を用いた。

【結果】Athlete 群およびSedentary 群の身長および体重 に有意な差は無かった。過去の運動歴は光れぞれ $12.1 \pm 3.0$ 年、 $2.8 \pm 3.4$ 年、推定最大酸素摂取量は $68.4 \pm 10.6$ $1 / \mathrm{min} / \mathrm{kg} 、 46.2 \pm 8.61 / \mathrm{min} / \mathrm{kg}$ であり、両群間に有意な差 か認められた ( も、両側の海馬尾部における灰白質量が多く、有意な差が 認められた ( p 〈0.0005、uncorrected)。両群間に抑うつ 度の有意な差はみられなかった (Athlete 群：CES-D ; 14.3土8.9、K10うつ尺度；18.3土7.2、Sedentary 群：

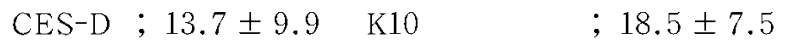
Athlete 群の左海馬尾部灰白質量と抑うつ度に有意な相関 がみられた (CES-D scale ; r=-0.43、 $\mathrm{p}=0.044 、 \mathrm{~K} 10$ j つ尺度； $\mathrm{r}=-0.47 、 \mathrm{p}=0.028)$ 。

【結論】運動経験が海馬尾部における灰白質量を増大させ る可能性が示唆された。運動経験の違いによる抑うつ度の 差はみられなかったが、Athlete 群において左海馬尾部灰 白質量と抑うつ度に相関がみられたことから、海馬が抑う つに関与している可能性が示唆された。
Key Word

セロトニン NPY 摂食
Key Word

海馬 抑うつ 運動 
17. PTU 曝露ラットの水迷路学習に及ぼす走運動トレー ニングの影響

○中野 裕史 ${ }^{1}$ 諏訪 雅貴 2 熊谷 秋三 $^{2}$

$\left({ }^{1}\right.$ 中村学園大学 人間発達学部、 ${ }^{2}$ 九州大学 健康科学也 ンター)

【目的】甲状腺ホルモンは中枢神経系の発達に影響を及ぼ す. 授乳中の母ラットに $0.02 \%$ プロピオチオウラシル

(PTU) を飲料水として投与し，母乳を介した甲状腺ホ ルモン抑制によって仔ラットの水迷路課題に対する学習能 カが低下する. 一方, 走運動卜レーニングはラットの水迷 路学習の成績を向上させると考えられている. 乥こで本研 究では, PTU 曝露ラットに走運動トレーニングを課すこ とにより学習能力の低下が回避できるかどうか検討した .

【方法】出産後から0.02\% PTU を飲料水として母ラット に3週間摂取させた．オス仔ラット $(\mathrm{n}=12)$ を3週齢時に 離乳させ，弚の後は通常の飲料水で飼育した (PTU 群) . この内，7匹には4週齢時より走運動トレーニング $(15 \mathrm{~m} /$ 分， 60分/日，5日/週）を4週間施した (PTUT 群). 出生後か ら水のみを捸取させたオス仔ラット 7 匹をコントロールと した (CON 群) .8週齢時にモリス水迷路学習課題を5日間 実施し，プラットホームまでの逃避潜時を測定した。翌日， 60秒間のプローブテストを行い，4分割したエリア内での 滞在時間を測定した．9週齢時に断頭屠殺し，採血および 海馬の摘出を行った 血清中の BDNF の測定を ELISA キッ 卜 (Promega) で行った .海馬のBDNF はウェスタンブロッ ティングにより確認し，NIH Image 1.63により数値化した。 【結果】 PTU ラットはCONラットに比べ, 学習開始2， 3，4日目におけるプラットホームまでの逃避潜時の有意な 遅延が認められた .一方, トレーニングを実施した PTUT ラットにおける有意な逃避潜時の遅延は, 学習開始2日目 のみであった . プローブテストの前半30秒間では，何れの 群もプラットホームが置かれていたエリアでの滞在時間が 最も長かった . PTU ラットと PTUT ラットでは, 後半30 秒間も同樣であり，プラットホームが置かれていたエリア での滞在時間には前半と後半で差がなかった．一方， CON ラットでは, プラットホームが置かれていたエリア での滞在時間が, 前半よりも後半で咸少しており，他のエ リアでの滞在時間が増加する傾向にあった . 血清 BDNF はPTUラットとCON ラットで差が認められず，PTUT ラットでは他の2群よりも有意に低下していた．海馬 BDNF はPTU ラットとCON ラットで差が認められず， PTUTラットでは他の2群よりも増加していた .

【考察】ラットでは乳児期の低甲状腺ホルモン暴露により 水迷路学習成績が低下するが, 弚れは血清 BDNF と海馬 BDNF との直接的な関連がないと推察され, 他の要因が影 響していることが示唆された .これらのラットに走運動卜 レーニングを実施すると，水迷路学習成績の低下が抑制さ れるが, 兴の際には海馬 BDNF の増加か関与しているも のと推察される. 同時に血清 BDNF も低下するが, 光の 生理学的意味は不明である.

Key Word

甲状腺ホルモン 水迷路学習 BDNF
18. 長期自発運動によるラットの海馬 BDNF と血清 IGF-I

○角田 聡、加藤 隼太 ${ }^{2}$ 、須田 和裕 ${ }^{3}$

( ${ }^{1}$ 大阪学院大学、東東工業大学、 ${ }^{3}$ 東京工業大学)

【目的】ラットやマウスの短期間自発運動で，海馬におけ る脳由来神経栄養因子 (BDNF)か増加し, 海馬神経細胞の 分化・増殖に関与することが知られている。また, 運動に よって合成が促進される成長因子の一つであるインスリン 樣成長因子-I ( IGF-I) も血液循環を介して脳神経細胞の分 化・増殖に作用すると考えられる。光こで本研究では, 現 在までに報告が少ない10週間のラット自発運動が海馬の BDNF と循環血液中 IGF-I および海馬 IGF-Iレセプターに 及ぼす影響について検討した。【方法】4週齢 Wister 系雄 ラットを自発運動群 $(n=10)$ と非運動群 $(n=10)$ に無作 為に分け，10週間飼育した。自発運動はラット用回転ケー ジを用い, 走行距離を測定した。飼育後麻酔下で全脳を摘 出し， $-80^{\circ} \mathrm{C} て ゙$ 涷結保存した。海馬を lysis bufferによって ホモジネイトし, 上清を用いBDNF (ELISA), IGF-Iレ セプター(ウェスタンブロット)を測定した。循環血 IGF-I (ELISA)の測定は心臓から全血を採取し，血清を分 離した後に測定に用いた。【結果】自発運動群は平均4.6土 $0.7 \mathrm{~km} /$ 週の走行距離に相当する運動を遂行した。海馬 $\mathrm{BDNF}$ 濃度は自発運動群が非運動群に比べて有意 ( $\langle 0.05)$ に高い值を示した。分析過程でサンプルを酸処理 した方法（受容体に結合しているBDNF を遊離させた総 BDNF) と酸処理しなかった方法 (受容体に結合していな いフリーの BDNF) の両測定においても同樣の結果が得ら れた。血清 IGF-I 濃度は, 自発運動群と非運動群で有意な 差は認められなかった。海馬 IGF-Iレセプタータンパク質 の発現は, 自発運動群が非運動群に比べて低下傾向を示し たが，有意な差は認められなかった。【考察】従来から自 発運動の初期 (3日目〜 7 日目) に海馬 BDNF が増加す ることが報告されているが, 本研究では 10 週間の長期自発 運動においても海馬 BDNF の増加が確認された。このこ とは，比較的短期間の自発運動のみならず 10 週間の長期自 発運動によっても海馬 BDNF 濃度が増加することが明ら かになった。すなわち, ストレスが少ない自発運動は海馬 神経細胞の分化・増殖に効果的な因子の増加を促すことが 示唆される。ところで, 循環血の IGF-I も関与すると考え られるので, 血清 IGF-I 濃度に着目して分析を行ったが， 血清 IGF-I 濃度には自発運動の影響はみられなかった。運 動による血清 IGF-I 濃度は, 運動中もしくは運動直後に上 昇するという報告もあり，今回の研究では採血の時間的問 題, 運動強度の問題等が影響したのかもしれない。また， 海馬 IGF-Iレセプターも自発運動群で若干低下したが, 有 意な差ではなかった。今後, 自発運動による海馬 BDNF と IGF-I の関係についてさらに検討する必要がある。

Key Word

自発運動 海馬 BDNF IGF-I 
19. 成体ラットの海馬歯状回における Mash1陽性細胞に 対する走運動の影響

○宇田 宗弘 ${ }^{1}$ 、増原 光彦 ${ }^{1} 、$ 上 勝也 ${ }^{1}$ ( ${ }^{1}$ 大阪体育大学大学院スポーツ科学研究科)

【緒言】 Mammalian achaete-scute homolog 1 (Mash1)は 神経新生に重要な役割を演じている転写因子である。 Mash1を発現する細胞 (Mash1十細胞) は成獣ラットの神 経新生部位である側脳室周囲 (SVZ) と海馬歯状回 (DG) の下層部位 (SGZ) に観察されている。SVZでは神経幹/ 前駆細胞 (NSPCS) から生じるアストロサイト及びニュー ロンの特徵を有しない一過性増殖細胞にMash1の発現が 認められる。しかしながら SGZにおける Mash1+細胞の 細胞タイプは明らかにされていない。また虚血のような神 経新生を高める刺激によって DG の Mash1+細胞数の増加 が報告されており、走運動も神経新生を高める刺激である ものの走運動が Mash1+細胞に及ぼす影響は十分に解明 されていない。光こで本研究は SGZ における Mash1+細 胞の細胞タイプを同定することに加えて、Mash1十細胞 に対する走運動の影響を検討することを目的とした。【方 法】実験動物には8週齡のウイスター系雄ラットを用いた。 ラットはRunning (R) 群と Non-Running (NR) 群に分けら れ、 $\mathrm{R}$ 群は $22 \mathrm{~m} / \mathrm{min}$ の速度で1日 30 分間のトレッドミル走 を7日間行った。また NR 群は1日30分間トレッドミル上に 放置し、これを7日間行った。7日目の走運動あるいは放置 を終えた12時間後に脳を摘出した。SGZにおける Mash1 十細胞と細胞タイプはMash1抗体、アストロサイトと NSPCs のマーカーである GFAP 抗体、神経芽細胞のマー カーである DCX 抗体、増殖細胞のマーカーである Ki67 抗体を用いた免疫染色により同定した。また SGZにおい て产れ光れのマーカー抗体で染色された細胞数を計測し定 量化した。【結果】 Mash1十細胞はR 群と NR 群の DGの SGZ に観察された。各々の群におけるほとんどの Mashl 十細胞は Ki67を発現する増殖細胞 (Mash1+/Ki67+細胞) であった。Mash1+細胞の細胞タイプは、各群において Mash1を発現するアストロサイトあるいは NSPCs (Mash1 十/GFAP +細胞) と神経芽細胞 (Mash1+/DCX +細胞) であることが分かった。しかし各群における Mash1+細 胞数に対する Mash1+/GFAP +細胞および Mash1+/DCX 十細胞の割合は両者ともに低かった。これらの結果は SGZに観察された多くの Mash1+細胞はアストロサイト、 NSPCs、神経芽細胞には属さないことを示し、SGZにお ける Mash1十細胞は、一過性増殖細胞であることを示唆 した。走運動に対する R 群と NR 群の Mash1+/Ki67+細 胞数の比較において、NR 群は R 群と比較して Mash1+ /Ki67+細胞数が有意に増加することを認めた。この結果 は走運動が一過性増殖細胞の増殖を刺激することを示唆し ている。これらの結果は、一過性増殖細胞は運動誘発性の 神経新生において新生ニューロン数の増加に貢献している 可能性が示唆される。

Key Word

走運動 神経新生 Mash1
20. 肥満ラットにおけるランニング中のセロトニン神経活動

○柳田 信也 ${ }^{1}$ 、北 一郎 ${ }^{2}$

( ${ }^{1}$ 東京都立大学 理学研究科、 ${ }^{2}$ 首都大学東京大学院 人 間健康科学研究科)

【目的】脳内セロトニン神経系は、うつ病やパニック障害 などの精神疾患と密接に関連しており、脳内セロトニン量 の減少がこれらの疾患の一因であると考えられている。ま た、セロトニン神経は不安やストレスを軽減し、平常心を 保つ役割を持つことがわかっている。これまで、ランニン グやジョギング、ヨガなどのリズム性のある運動を行うこ とによってセロトニン神経の活動が六進することが報告さ れており、このセロトニンの働きによって運動時のストレ ス反応の軽減や気分の向上がもたらされることが示唆され ている。しかしながら、一般的に、肥満者が運動を行う場 合、運動に対して嫌悪感や不快感を覚えると言われ、非肥 満者に比べ、運動が強いストレスとなっていることが考え られる。このことは、運動時のセロトニン神経の活動が肥 満者と非肥満者では異なることを示唆する。光こで、本研 究では、肥満ラットを用いて急性トレッドミル走を行わせ た時の、吻側縫線核群(DRN,MRN)のセロトニン神経活動 と同時に、ストレス反応の中枢である視床下部室傍核 (PVN)のコルチコトロピン放出ホルモン $(\mathrm{CRH})$ 神経、およ びストレスの評価、判断と関連がある前頭前野 (PFC)の神 経活動を、免疫組織化学的手法を用いて検討することを目 的とした。【方法】実験には雄のZucker ラットを用いた。 レプチン受容体変異型の肥満ラット(Obese) を肥満動物モ デルとし、ワイルドタイプをコントロールラット (Control) とした。Obese および Control を光れ光れ運動群 $(\mathrm{Ex})$ と非 運動群 (Non-Ex) に分け、Ex にはトレッドミルにて $17 \mathrm{~m} / \mathrm{min}$ の速度で1時間の走行を行わせた。Non-Ex は、 通常の飼育されているケージで1時間の安静とした。トレッ ドミル走およびケージでの安静開始後90分にすべてのラッ 卜は環流・固定され、即座に脳か摘出された。摘出された 脳は前額面で $40 \mu \mathrm{m}$ の厚さでスライスされ、神経活動の 指標となる $c-F$ OS に対する免疫染色が行われた。弚の後、 DRN およびMRN が含まれる切片に関しては5-HT (セロ トニン)抗体、PVN が含まれる切片に関しては CRH 抗体 で二重染色を行った。【結果】本研究で検討したすべての 脳部位 (DRN，MRN，PVN，PFC)において、Exでは Non-Ex に比べ、c-Fos 発現数の有意な増加が見られた。 さらに、Exにおいては MRN の c-Fos $/ 5 \mathrm{HT}$ 二重標識細胞 数は、Obese の方が Controlよりも有意に低く、DRNに おいても Obese の方が Control よりも低い傾向にあった。 また、PVN における c-Fos/CRH 二重標識細胞数は Obese の方が Controlよりも有意に高く、 $\mathrm{PFC}$ の $\mathrm{c}-\mathrm{Fos}$ 発現量 は Obese の方が Controlよりも有意に低かった。【考察】 セロトニン神経は PVNや PFC の神経活動を修飾し、ス卜 レス反応を軽減したり、ストレスの評価・判断の機能を高 めたりすることが示唆されている。したがって、肥満ラッ 卜においては急性運動時のセロトニン神経の活動が低いた め、運動時のストレスを抑制する機能が低く、運動がより 強いストレスとなっている可能性が示唆される。本研究の 結果は、肥満者の運動処方を考える際、光の心理状態も十 分に考慮する必要性を示唆する。

Key Word

肥満ラット セロトニン ストレス 


\section{1. 定期的な運動と血清 BDNF の関連性}

○野藤 悠 ${ }^{1}$ 諏訪 雅貴 2 、森山 善彦 1 、中野 裕史 ${ }^{3} 、$ 佐々木 悠、熊谷 秋三 ${ }^{2}$

( ${ }^{1}$ 九州大学大学院 人間環境学府、 ${ }^{2}$ 九州大学 健康科学 センター、 ${ }^{3}$ 中村学園大学 人間発達学部、 ${ }^{4}$ 福岡大学筑紫 病院)

【緒言】脳由来神経栄養因子 ( Brain-derived neurotrophic factor; BDNF ) は、脳の可塑性に影響する神経栄 養因子であり、神経の成長、分化、生存を保護する特性を 有している。さらに海馬におけるシナプス長期増強に関与 し、視床下部では捸食行動やエネルギー代謝の制御にも関 与していることが明らかにされている。これまで自発運動 は海馬等における BDNFmRNA、タンパクの発現を増加さ せ、BDNF ヘテロノックアウトマウスでは活動量が高い ことから BDNF は身体活動とも関連していることが予測 される。しかしながら、身体活動量と血清 BDNF との関 連性に関して、ヒトを対象に検討した報告はない。光こで 本研究では、非競技者と競技者を対象に比較検討を行った。

【方法】対象者は、日常的な運動を 1 年以上行っていない 非競技者群 (男性 15 名、年齢 $22.3 \pm 1.2$ ) と定期的な運 動を週4回以上行っている競技者群（男性13名、年齢 21.6 \pm 0.9 ) とした。血清 BDNF は ELSA 法で測定した。また、 身体組成、身体活動量（ライフコーダー；スズケン社製）、 および精神・心理的健康状態（GHQ-28、STAI）を調査 した。身体活動量は採血までの1週間連続測定した。【結果 と考察】身長、体重、BMI、体脂肪率に両群の差はなく、 またメンタル状態にも差は認められなかった。一方、総エ ネルギー消費量、運動によるエネルギー消費量、歩数、は 運動群で有意に高かった。またライフコーダーで得られた データより、運動時間、推定平均運動強度 ( =運動量/体 重/運動時間 ) を算出したところ、運動群の方が有意に高 値を示した。競技者群の血清 BDNF 濃度 (19.65 $4.35 \mathrm{ng} / \mathrm{ml})$ は、非競技者群 $(23.80 \pm 2.90 \mathrm{ng} / \mathrm{ml})$ に比 べ有意に低值であった。さらに、血清 BDNF は身体活動 量と有意な負の相関（総エネルギー消費量 : $r=-.507$, 運動によるエネルギー消費量： $r=-.502$, 歩数： $r=-.482$ ) も認められた。また運動時間と血清 BDNF は負の相関を 示した $(r=-.423)$ が、推定平均運動強度とは相関は認め られなかった $(r=-.196)$ 。以上の成績から、身体活動は 血清 BDNF と関連することが示唆されたが、弚の関連性 には運動強度よりも運動時間の関与が強いことが示唆され た。
22. 一過性の運動後の late Contingent Negative Variation ( CNV) の変動

○東浦 拓郎 ${ }^{1}$ 、西平 賀昭 ${ }^{1}$ 、紙上 敬太 ${ }^{1}$ 、金 勝烈 ${ }^{1} 、$ 林 久仁則 ${ }^{1}$

( ${ }^{1}$ 筑波大学大学院 人間総合科学研究科)

目的：以前，我々は一過性の運動前後に実施する課題の夕 イミングの違いが脳機能に及ぼす影響を検討するため，30 分間の中等度強度 (65\%HRmax) の運動前 (pre-exercise), 直後 (post-exercise 1), 運動によって上昇した体温及び 心拍数が運動前の值に戻った時点 (post-exercise 2) にお いて Go/NoGo 反応時間 (RT) 課題を行った. 光の結果, 認知機能を反映する事象関連電位 (ERP) の Go P3 と NoGo P3振幅は post-exercise 1でのみ増大し, 運動直後に 認知機能の促進がみられることを報告した (ACSM annual meeting, 2006) . この Go/NoGo RT 課題時には上述の ERP 成分の他に運動準備に関連する Late Contingent Negative Variation (CNV) も出現する. 光こで, 本発表では運動 前後における Late CNV の変動について報告する . 方法：

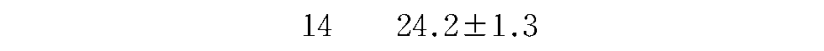

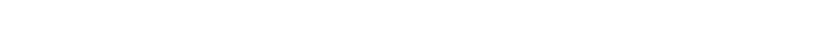
は別の日にランダムに行われた . 運動条件は前述のとおり， 30分間の中等度強度 (65\%HRmax) の運動前 (pre-exercise)， 運動直後（post-exercise 1)，運動によって上昇した体温 及び心拍数が運動前の值に戻った時点 (post-exercise 2) において Go/NoGo 反応時間 (RT) 課題を行った.コント ロール条件においては, 30分間の読書の前後に運動条件と 同じタイミングでGo/NoGo RT 課題を実施した. 結果 : 行動指標である筋電図反応時間に関しては変化が認めらな かった 、一方，Late CNV 振幅には“条件”と“課題の実 施タイミング”の要因に交互作用がみられ，運動条件にお いてのみ pre-exerciseに比べ post-exercise 1, post-exercise 2において振幅の増大か認められた . 考察 : EMG-RT を変化させるには至らなかったものの，30分間 の中等度強度の運動後には Late CNV の反映する運動準備 過程の機能促進が起こることが示唆された．また， Late CNV 振幅の増大は post-exercise 1 のみならず, post-exercise 2においても観察されたことから，Go P3， あるいは NoGo P3と異なる可能性が考えられる . Late CNV の発生には運動関連領野も関わっていることから， 運動による影響をより強く受けたのかもしれない .
Key Word

脳由来神経栄養因子 身体活動量 消費エネルギー
Key Word

一過性の運動 運動準備 late CNV 
23. ガラニン様ペプチド( GALP)はオレキシンニューロン を介して摂食促進をする

○竹ノ谷 文子 ${ }^{1}$ 、影山 晴秋 ${ }^{2}$ 、十枝内 厚次 ${ }^{3}$ 、北 徹 朗 4 、竹内 正雄 ${ }^{1}$ 、堀江 繁 4 、山本 憲志 ${ }^{5}$ 、塩田 清二 2

$\left({ }^{1}\right.$ 星薬科大学 薬学部 体育学、 ${ }^{2}$ 昭和大学 医学部 第 一解剖学、 ${ }^{3}$ 宮崎大学 医学部 第三内科、 ${ }^{4}$ 東海大学 体 育学部 体育学、 ${ }^{5}$ 日本赤十字北海道看護大学 体育)

【はじめに】ガラニン樣ペプチド(GALP)は G タンパク質 共役受容体のリガンドとしでブタ視床下部より同定された 攝食調節作用をもつ生理活性ぺプチドである。我々はこれ まで、免疫組織化学法を用い、ラット脳内における GALP ニューロンと光の他の摂食調節物質 (ニューロペプチドY (NPY)、オレキシン、メラニン凝集ホルモン $(\mathrm{MCH})$ など) との神経相関を観察し、GALP ニューロンは視床下部・ 弓状核において、摂食促進作用を持つ NPY、オレキシン ニューロンの求心性の神経支配を受ける一方、外側視床下 部のオレキシンおよび $\mathrm{MCH}$ (メラニン凝集ホルモン) ニューロンに投射し遠心性の神経支配し、GALP は複雑 なニューロンネットワークを構築して摂食調節を行ってい ることを形態学的に明らかにした (竹ノ谷、2002、2003年)。 しかし、生理学的に GALPがオレキシンまたは MCH を介 して捸食即調節作用を行っているかどうかは不明である。

【目的】GALP 標的ニューロンを同定し、さらに光のペ プチドの阻害実験を行うことで、GALPによる生理機能 的な摂食経路を明らかにする。

【方法】ウィスター雄ラットを用い、GALP 脳室内投与 によるオレキシンおよび MCH ニューロンのc-Fos 発現を 観察した。また免疫電顕的にGALP とオレキシンニュー ロンの神経相関の詳細を観察した。さらに抗オレキシン IgG の投与による攝食量を測定した。

【結果およびまとめ】GALP 投与 90 分後、外側視床下の オレキシンニューロンの cFoS 発現が観察されたが、 $\mathrm{MCH}$ ニューロンの cFos 発現は見られなかった。電顕的に GALP とオレキシンニューロンの神経相関を観察したとこ ろオレキシン陽性細胞体と GALP 陽性軸索とのシナプス 形成を観察した。また、シナプスのタイプを調べたところ、 細胞一軸索間シナプスおよび細胞-樹状突起間シナプスの2 つの形成が観察された。さらにオレキシンの中和抗体を用 いて内因性のオレキシンを阻害したところ、抗オレキシン IgG の前投与は GALP による過食を抑制した。これらの観 察結果から、GALP の捸食促進経路の一つとして、オレ キシンを介して捸食促進する系が存在することが明らかに なった。

Key Word GALP 摂食調節 オレキシン
24．運動習慣と海馬形態および心理尺度の関係

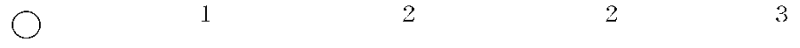
石井 賢治”、菊地 次郎 ${ }^{3} 、$ 小川 静香 ${ }^{3}$ 、権藤 雄一 ${ }^{4}$ 、 竹倉 宏明 4

( ${ }^{1}$ 東北大学 高等教育開発推進センター、 ${ }^{2}$ 明治安田厚生 事業団 体力医学研究所、 ${ }^{3}$ 東北大学大学院 医学系研究 科 運動学分野、 ${ }^{4}$ 鹿屋体育大学大学院 スポーツパフォー マンス系)

【目的】海馬が記憶や学習に関わる部位であることは良く 知られているが、感情や情動の制御にも中心的な役割を果 たしている。また運動が精神的健康の維持・増進に効果的 であることが心理学的研究から示唆されているが、光の理 科学的メカニズムはほとんど分かっていない。この研究は ヒトを対象にMRI を用いて、運動習慣が海馬形態におよ ぼす影響を観察し、また海馬形態と質問紙法による心理ス コアとの関係に検討を加えることを目的とした。【方法】 被験者は右利きの非喫煙者である健康な男子学生、鍛錬者 群 22 名 $(21.8 \pm 2.2$ 才)および非鍛錬者群 26 名 $(22.2 \pm 2.2$ オ)とした。MRI は T1強調画像を TR/TE: 50/2.4 msec, FA: $45^{\circ}$, number of excitations: 1 , 有効視野: $22 \mathrm{~cm}$, matrix size: $256 \times 256$, スライス厚: $2 \mathrm{~mm}$ の条件で撮影した。 脳画像処理および解析は、optimized voxel-based morphometry (VBM)法を用いた。また、心理スコアは質問紙 形式で主観的幸福感尺度、自己受容測定尺度、特性的自己 効力感尺度、アイデンティティー尺度を用いて測定した。 【結果および考察】鍛錬者群の運動歴は約 $12.0 \pm 3.0$ 年、 非鍛錬者群は $2.4 \pm 3.3$ 年で、両群間に有意な差か認められ た ( $\mathrm{p} く 0.05)$ 。また最大酸素捸取量は鍛錬者群で68.4 $10.61 / \mathrm{min} / \mathrm{kg}$ 、非鍛錬者群で $46.2 \pm 8.61 / \mathrm{min} / \mathrm{kg}$ であり、 両群間に有意な差が認められた $(\mathrm{p}<0.05)$ 。optimized VBM の結果、鍛錬者群の両側の海馬尾部における灰白質 量が非鍛錬者群よりも多いことが分かった ( p く 0.05 ，cor rected volume)。この結果から若年においても運動習慣に より海馬尾部の灰白質量が増大する可能性が示唆された。 また左海馬尾部の灰白質量と、自己受容能 $(\mathrm{R}=0.36, \mathrm{P}=$ $0.064)$ および主観的幸福感の間に相関傾向 $(R=0.34, P=$ 0.080)か認められた。この結果は非鍛錬者においては主観 的幸福感や自己受容に対して左海馬尾部か関与している可 能性を示唆するものである。

運動習慣 心理尺度ＭRI 
25. Golden Syrian Hamster の摂食行動および䬺蓄え行 動に及ぼす運動の影響と視床下部弓状核における ニューロペプチド Y 遺伝子発現の変化

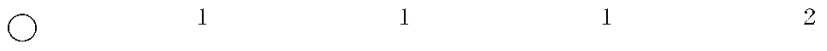
鈴木 政登 ${ }^{3}$ 柴崎 敏昭 ${ }^{1}$

( ${ }^{1}$ 共立薬科大学 薬物治療学講座、 ${ }^{2}$ 慈恵医大 リハビリ テーション医学講座、3慈恵医大 臨床検査医学講座)

【背景および目的】肥満改善を目的とした介入は色々と試 みられているが，長期間に渡って肥満を克服できる者は少 なく，体重減少後には過度の攝食え進と体重の回復(リバ ウンド)現象が観察される，従って，体重減少を目的とし た介入では，体重減少後に摂食行動を惹起しにくい介入方 法の開発か望まれている.

我々は, 過食性肥満モデルの OLETF ラットを用いた先 行研究において, 摂食行動を惹起する視床下部弓状核 ( ARC)のニューロペプチドY (NPY)遺伝子発現が食事療 法後に増加し, 運動療法後には減少する傾向を観察した . しかし，このとき運動療法群で観察された中枢の変化は， 食事療法群との間に有意差を認めたものの, ad lib 対照群 との間に差は認められなかった .この原因の一つとして , 対象としたラットの運動量が少なかったことと，ラットの 摂食行動や身体活動量に明確な日内リズムが観察されな かった点が関与していた可能性が示唆された .

そこで本研究では, 運動量が多く身体活動の日内リズム が明確で, さらに餌蓄え行動によって比較的長期間の攝食 欲が評価可能な Golden Syrian Hamster を用いた検討を 行った。

【研究方法】被験動物としては, 成長に伴う体重増加が比 較的安定した44週齢の雄性 Golden Syrian Hamster を用い た。 Hamster は自由攝飭・自由飲水環境下で，実験開始1 週間前より個別ヶージを用いた予備飼育を実施し，実験期 間中は毎朝10時に体重, 摂餌量および飭の持ち出し量を計 測した . 運動群は , 運動開始時に回転ケージへ続く入り口 扉を開け，自発的走運動を行わせた。

観察期間終了後 脳スライス標本から ARC 領域を摘出し， RT-PCR 法にて NPY およびレプチンレセプター(Ob-Rb) の遺伝子発現を半定量評価した . また採取した血漿を用い て，ELISA 法により血中レプチン濃度を評価した。

【結果および考察】光の結果, Hamster の攝飭量および 飭蓄え行動は運動開始と供に減少し, 光れに伴う体重およ び内藏脂肪重量の有意な減少が観察された . 血中レプチン 濃度は運動によって著減したが, ARCの Ob-Rb 遺伝子発 現に変化は認められなかった .レプチンが負に制御する ARCの NPY 遺伝子発現は有意に減少していたことから， 運動時における捸食行動の抑制機序の一部は, ARCの $\mathrm{Ob}-\mathrm{Rb}$ と NPY 遺伝子発現との間に存在する可能性が示唆 された .

Key Word

ハムスター 摂食行動 ニューロペプチドY
26. 異なる強度のトレッドミル走運動がラットの空間学習 能力と海馬局所血流量に及ぼす影響

○花岡 勇太 ${ }^{1}$ 、征矢 英昭 ${ }^{2} 、$ 西島 壮 $^{3}$

( ${ }^{1}$ 筑波大学大学院 体育研究科、筑波大学大学院 人間 総合科学研究科 運動生化学研究室、3筑波大学大学院 人間総合科学研究科)

【目的】記憶・認知に関与する海馬は脳の中でも最も可塑 性の高い部位である。これまで多くの研究により、運動が 海馬の可塑性を高めることが報告されている。しかしなが ら、これらの報告における運動樣式は回転ホイールによる 自発運動であるため、運動のどのような要因 (強度、時間、 頻度など) によって海馬の可塑性が高まったのかは明らか になっていない。 $50 \sim 60 \% \mathrm{VO}_{2} \max$ 付近に存在する乳酸性 作業閾値 (LT) を境に、ACTHやグルココルチコイドの 分泌が進することから、LT 強度以上の運動は生体に とってストレスとなる。海馬はストレスに対して非常に脆 弱な部位であり、慢性的なストレスによって海馬の可塑性 に負の影響を与えるという報告もされている。したがって、 ストレス反応がえ進するような高強度運動では、海馬の可 塑性が高まらないかもしれない。乥こで本研究では、運動 強度に着目し、空間学習能力と運動時の海馬神経活動の活 性化という2つの指標から、異なる強度のトレッドミル走 運動が海馬の可塑性に与える影響を検証した。【方法】 12 週齢の Wistar 系雄ラットを用いた。ラットを対照群 $(0$ $\mathrm{m} / \mathrm{min})$ 、低強度群 $(15 \mathrm{~m} / \mathrm{min}) 、$ 高強度群 $(40 \mathrm{~m} / \mathrm{min})$ にグ ルーピングし、1日60分、6週間のトレッドミル走運動トレー ニングを課した。トレーニング終了後、全てのラットに対 してモリス水迷路課題（MWM）を行わせた。MWM は4 日間の空間学習逃避訓練と最後の訓練の24時間後に行われ るプローブテストによって構成されている。 MWM を行っ た翌日、海馬背側 CA1領域に、海馬局所血流量 (Hip-CBF) 測定用のガイドカニューラを挿入した。体重の回復と馴化 実験の後、全てのラットに $10 \mathrm{~m} / \mathrm{min}$ のトレッドミル走運 動を30分間行わせ、安静時の $\mathrm{Hip}-\mathrm{CBF}$ を $100 \%$ として、卜 レッドミル走運動中の Hip-CBF の増加率を測定した。 MWM、 Hip-CBF の測定・分析には、水迷路専用分析装 置 (35C67-AC5, PANLAB 社製)、レーザードップラー血 流計 (FLO-Cl, OMEGAWAVE 社製) を关れ玍れ用いた。 【結果】副腎の肥大の結果から、トレーニングがどのよう なものであったかを示す。空間学習逃避訓練を通じて、プ ラットフォームへの到達時間に群間差はなかったが、プ ローブテストにおいて、対照群、高強度群と比較して、低 強度群の成績が有意に高かった。また走運動中の Hip-CBF に関しては、高強度群と比較して低強度群にお いて、安静時の Hip-CBF に対する増加率が有意に高かっ た。【結論】本研究においても、先行研究と同樣に走運 動トレーニングにより空間学習能力は向上したが、光の効 果は低強度のみでみられ、高強度の走運動卜レーニングで は空間学習能力は向上しなかった。また、低強度の走運動 トレーニングと比較して、高強度の走運動トレーニングで は走運動時の海馬神経活動の活性度が低い可能性が示唆さ れた。これらの結果から、海馬の可塑性を高めるためには 低強度の運動が適しており、高強度の運動ではストレスホ ルモンによる負の影響か溞くなり、海馬の可塑性が高まら ない可能性が示唆された。

Key Word 空間学習能力 海馬局所血流量 運動強度 


\section{7. 長期学習による運動イメージの構築と大脳運動野の皮 質内興奮性変化}

○丸山 敦夫 ${ }^{1}$ 前田 雅人 、衛藤 誠二 2 川平 和美 ${ }^{2}$ ( ${ }^{1}$ 鹿児島大学教育学部、年鹿児島大学医歯学総合研究科)

【目的】運動イメージは明確な動きを伴わない動作の心 的リハーサルとして定義される。fMRI の研究では運動イ メージ中に活性される脳の多くの領野 (前頭前野、補足運 動野、小脳を含む) は、明確な動作で活性される領野と同 じであることが指摘されている (Decety et al 1994, Stephan et al. 1995, Gerardin et al 2000, KuhtzBuschbeck et al 2003)。生理学的研究では運動イメージも また皮質運動野上に閾值下の効果をもたらすことか指摘さ れている。運動イメージは、皮質脊骾路の興奮性を促進し、 皮質内抑制を減らすと言われ、同じ目的筋の随意活動時に 現れる興奮性と類似している (Hashimoto and Rothwell 1999, Rossini et al. 1999, Facchini et al. 2002, Abbruz. zese et al. 1999)。乥こで、本研究は初心者に長期のタイ ピング学習を行わせ、新しい動作技術を構築した後、タイ ピングイメージ時に経頭蓋磁気刺激法(TMS)による二重 TMS で刺激することによって皮質脊髄路系 (motor evoked potential; MEP), 皮質内抑制(short interval intracortical inhibition; SICI)および促通 (intracortical facilitation; ICF) の興奮性がどのように変化するかを検討した。【方法】 被験者は7名のタイピング初心者であり、2回のタイピング イメージを想起し、弚の後30分の短期学習を行うように指 示された。二重 TMS は安静時、2回のタイピングイメー ジ中およびイメージの前後、さらに短期練習前後に実施さ れた。大脳皮質運動野の MEP、SICI およびICF は、テス 卜刺激、二重刺激間隔 $2 ， 3 ， 4 \mathrm{~m} \mathrm{~s}$ (SICI) および 10 ， $15 \mathrm{~m} \mathrm{~s}$ (ICF) によって評価された。長期学習は、キー ボードタイピング練習を10日間、毎日30分間行い、前後の タイピング成績も評価した。【結果】1) タイピングの初 心者がタイピングのイメージをしても、30分間のタイピン グ練習後も MEP、SICI/ICF には変化がなかった。2) 被 験者が10日間一日30分間タイピングのトレーニングを行っ た結果、タイピング率と正確性が有意に高まった。タイピ ングイメージ時に、有意な MEP の増加と SICI の低下を導 いた。しかし、ICF に变化は見られなかった。3）長期 学習後で、30分の短期練習をした後には、有意なSICIの 低下が見られた。【結論】初心者にとって長期学習前の タイピングイメージ時の皮質内抑制および促通は安静時と 比へ、顕著な変化はなかったが、学習後のイメージ中には 皮質内抑制が低下した。乥れに対して皮質内促通は顕著な 変化を示さなかった。以上のことから、長期学習による運 動イメージの構築はイメージ時に皮質脊䯣興奮性の増加お よび大脳皮質内抑制の低下を引き起こすことが明らかに なった。

Key Word 運動イメージ 長期学習 皮質内抑制
28. 物体持ち上げ時に視覚から流入する大きさ情報は重さ 知覚にとってバイアスか貢献要因か?

○川合 悟 ${ }^{1}$

( ${ }^{1}$ 帝塚山大学)

【目的】物体持ち上げ時には「視覚から得られる大きさ情 報」が関与し(Gordon 1991)、持ち上げ後の重さ知覚にも 影響することが知られている (Ross 1969)。これまで、持 ち上げ時に「直接手指から得られる大きさ情報」が重量情 報と規則的に統合され、重さを構成する重要な要因である ことを報告してきた(Kawai 2002，2003)。弚こで、「視覚 から得られる大きさ情報」も、知覚される重さを構成する 決定要因なのか、乥れとも単なるノイズであるのかを検証 した。【方法】実験机上に2つの Cube がワイヤーを介し左 右に吊り下げられた。コンピューターで描いた Cubeが、 ハーフミラーを介して実際の各 Cube に重なって見えるよ う調節した。グラフィック Cube は実際の Cube に同期し て動いた。基準刺激となる Cube (左) は一定 (一辺 $5.0 \mathrm{~cm}$ 、 $30 \mathrm{~g})$ だったが、比較刺激となる Cube (右) は光の質量 が10，20，25，28，30，32，35，40，50g に変化された。被 験者はワイヤーを介して基準 Cube を持ち上げ、感じた重 さと同じに感じる (主観的等価点：PSE) まで比較 Cube のグラフィックの大きさか調節された。いずれの質量条件 においても試技の最初は比較 Cube の一辺は $5.0 \mathrm{~cm} て ゙$ 基準 Cube と同じだった。従って比較 Cube の質量が(1) $30 \mathrm{~g}$ 末

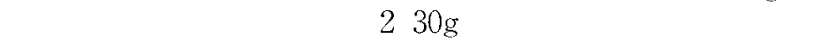
いと回答された。光の後 (1)の場合には比較 Cube の大き さを徐々に小さく、(2)の場合には大きさを徐々に大きく して、被験者が基準 Cube と同じ重さに感じるまで調整を 繰り返した。被験者に対して各質量につき 3 試技が実施さ れた。質量条件は擬似ランダム的に提示された。16名の被 験者の PSE を各質量について求め、弚の平均值を乥れ光 れ求めた。【結果】各試技の最初の比較 (基準 Cube と比 較 Cube の重量は異なるが大きさが同じ) 場合に、比較 Cube の重さの大小を正確に判断できたのは、全試技 (各48 試技) のうち $10 \mathrm{~g}$ で 48 試技、 $20 \mathrm{~g}$ で41試技、25g で25試技、 $28 \mathrm{~g}$ で13試技、32g で8試技、 $35 \mathrm{~g}$ で31試技、 $40 \mathrm{~g}$ で 42 試技、 $50 \mathrm{~g}$ で48試技だった。20g から $40 \mathrm{~g}$ の範囲では、大きさの 調節によってすべての試技において PSE を見出すことが できたが、10g 条件では17試技において大きさを最小限 (一 辺 $0.5 \mathrm{~cm})$ にしてもPSE は見出せなかった。一方、 $50 \mathrm{~g}$ 条件では 12 試技において大きさを最大限 $($ 一辺 $16 \mathrm{~cm})$ に しても基準 Cube と同じ重さになる大きさを見出すことが できなかった。PSEすなわち、基準 Cube (一辺 $5.0 \mathrm{~cm}$ 、 $30 \mathrm{~g})$ の重さと同じ重さに感じたときの比較 Cube の大き さの平均値 (SD) は、比較 Cube の質量が $10 \mathrm{~g}$ で一辺が1.43 $\pm 0.85 \mathrm{~cm} 、 20 \mathrm{~g}$ で4.06 $\pm 0.75 \mathrm{~cm} 、 25 \mathrm{~g}$ で $4.65 \pm 0.21 \mathrm{~cm}$ 、 $28 \mathrm{~g}$ で4.84 $0.19 \mathrm{~cm} 、 32 \mathrm{~g}$ で $5.10 \pm 0.16 \mathrm{~cm} 、 35 \mathrm{~g}$ で 5.53 $\pm 0.36 \mathrm{~cm} 、 40 \mathrm{~g}$ で $5.92 \pm 0.63 \mathrm{~cm} 、 50 \mathrm{~g}$ で $10.60 \pm 2.94$ $\mathrm{cm}$ であつた。質量と大きさの関係は、 $20 \mathrm{~g}$ から $40 \mathrm{~g}$ の範囲 では直線性 $(y=0.0912 x+2.28, R 2=.989)$ を示したが、 $10 \mathrm{~g}$ から $50 \mathrm{~g}$ の範囲に広げるとこの関係が崩れた。【考察】 重量差が $10 \mathrm{~g}$ の範囲では、重量と大きさには規則的な統 合がみられたが、重量差が光れよりも大きくなると炎の関 係が不安定になり、また必ずしもすべての被験者で統合が みられなかった。このことから持ち上げ時に流入する視覚 からの大きさ情報は、重さの決定的な要因ではないと推察 された。

Key Word

持ち上げ運動 重さ知覚 視覚情報 
29.上肢および下肢の同時ペダリング運動における自動制 御機構

○坂本 将基 ${ }^{1}$ 、田添 歳樹 ${ }^{1}$ 、遠藤 隆志 ${ }^{2}$ 、中島 剛 ${ }^{3}$ 、 塩澤 伸一郎 4 、大森 茂樹 4 、立松 幹浩 4 、小宮山 伴 与志 5

( ${ }^{1}$ 東京学芸大学大学院、 ${ }^{2}$ 順天堂大学、 ${ }^{3}$ 国立身体障害者 ハビリテーションセンター、年葉大学大学院、年葉大学 教育学部)

【目的】上肢および下肢ペダリング運動時の筋活動は, 脊 髄内に存在するパターン発生器により発現すると考えられ ている. 各肢に存在するパターン発生器の活動は, ペダリ ング運動の自動的な制御を可能にすると考えられている． 近年，下肢ペダリング遂行中に一側肢で誘発される反射は 対側肢の運動に強い影響を受けるが，上肢ペダリングでは この影響が弱いことが報告された .この結果は, 上肢ぺダ リング中の左右肢の神経学的連結は下肢の兴れと比して弱 い可能性を示唆する. 弚こで我々は, 上肢ペダリング運動 は下肢ペダリング運動に比して自動的な制御が弱いという 仮説を立てた . 本研究は，この仮説を検証するために上肢 ペダリングと下肢ペダリングの自動制御が視覚または聴覚 的フィードバックにより受ける影響について検討した【方 法】被験者は機械的に連動していない2つの自転車エルゴ メーターを用い, 座位にて上肢と下肢の同時ペダリング運 動を行った . 同時ペダリング運動中に一方の肢のペダリン グを意識させないようにするために，他方の肢の速度を フィードバックさせた . 弚のため被験者には，上肢または 下肢ペダリングの速度を視覚的もしくは聴覚的にフィード バックさせ , フィードバックをしていない肢のペダリング 運動は各被験者の最も行いやすい速度で遂行させた．弚の 際，上肢および下肢ペダリングの速度のばらつきを観察し た .フィードバックする速度は $30,45,60 \mathrm{rpm}$ であった . 被験者には, 速度のフィードバックをしていない肢のペダ リング運動には意識を向けないように指示した .【結果】 上肢ペダリングの速度のばらつきは, 被験者が上肢の速度 をフィードバックしたときに比して下肢の速度をフィード バックしたときに有意に増大した．しかしながら，下肢ぺ ダリングの速度らつきは, 上肢の速度のフィードバックの 有無によらず一定であった . また, フィードバックする速 度や方法 (聴覚的もしくは視覚的) が異なってもこれらの 動態は堅持された。【考察】近年、ヒトにおいても四足 歩行動物と同樣に、下肢のみならず上肢にも脊䯣パターン 発生器が存在すること、ならびに下肢のペダリング運動と 同樣に上肢ペダリング運動も脊髄パターン発生器により駆 動されていると示唆されている。本研究では, 上肢もしく は下肢のペダリングの速度をフィードバックさせ、正確な ペダリング速度の維持を意図させた結果、上肢ペダリング 運動は, 下肢ペダリングに比して速度の変動が有意に大き くなった .これらの結果は, 上肢と下肢のパターン発生器 間にはカップリングが存在するが、下肢のパターン発生器 は上肢の关れに比して自律性か強い可能性を示唆する。

Key Word

上肢ペダリング 下肢ペダリング 自動制御

\section{0．直立姿勢制御と 眼球運動の関係}

○内山 応信 ${ }^{1}$ 、出村 慎一 ${ }^{1}$ 、中田 征克 ${ }^{2}$ 、山田 孝祯 ${ }^{3}$ 、 野田 政弘、辛 紹熙

( ${ }^{1}$ 金沢大学 大学院 自然科学研究科、防衛大学校、 ${ }^{3}$ 福 井工業高等専門学校、 ${ }^{4}$ 仁愛大学、 ${ }^{5}$ 金沢大学 大学院 教 育学研究科)

【目的】本研究の目的は, 直立時の固定された視標を注視 するときの眼球運動が，姿勢安定性に及ぼす影響を検討す ることであった .【方法】健常大学生男子10名が, 眼球の 動きを制御する2種類の実験条件のもと, 足圧中心 (COP) 動摇および眼電位（EOG）（水平および垂直方向）の測定 に参加した。.Space-fixed 注視点条件では, 被験者は眼球 から $1 \mathrm{~m}$ 先のスクリーンに固定された注視点を注視し立位 を維持した．Head-fixed 注視点条件では，被験者は上述 のスクリーン上において頭部動摇に同調して動く注視点を 注視し立位を維持した．前者の条件では，被験者の眼前の スクリーン上に固定された注視点を注視するため, 身体動 摇に伴う頭部動摇のため眼球運動が生じる．後者の条件で は, 被験者の頭部動摇に同調し動く注視点を注視するため 眼球運動が抑制される.また両条件において被験者の周辺 視野に，視覚的手がかり (visual cue) (水平および垂直方 向のライン) を提示した。したがって, Head-fixed 注視 点条件では直立姿勢維持中に眼球運動を抑制する代わりに， 網膜上における周辺視野広範囲の視覚像の動き，つまり retinal slip が生じると仮定される．COP 動摇は，動摇4因 子 $(\mathrm{F} 1$ : 動摇速度, $\mathrm{F} 2$ : 前後方向動摇量, F3 : 左右方向 動摇量，F4：高周波数帯域パワースペクトル) で評価した。 眼球運動（水平および垂直方向）は, 眼電位 $(E O G)$ から 変換し求めた角度時系列データから, 平均眼球運動角度を 求め評価した。【結果と考察】二要因に対応のある分散分 析 (眼球運動方向 $\times$ 実験条件) と多重比較検定の結果，両 実験条件において, 眼球運動角度は垂直方向の方が水平方 向成分よりも有意に高かった . また両方向の平均眼球運動 角度は, Space-fixed 注視点条件の方が Head-fixed 注視点 条件よりも有意に高かった . 対応のある一要因分散分析お よび多重比較検定の結果，F1，2および3は頭部固定注視 点条件の方が有意に高かった 、【結論】本研究の実験条件 下においては，ヒトが空間的に固定された対象物を注視し 立位を維持する場合，眼球運動により生じる網膜外の感覚 情報は, $\mathrm{COP}$ 動摇の速度, 前後および左右方向の動摇量 を減少させる可能性が示唆された .

Key Word

直立姿勢 足圧中心動摇 眼球運動 
31. シンコペーション・モードにおける発話と手指の運動 の相互作用 ( 2)

○乾 信之 ${ }^{1}$

( ${ }^{1}$ 鳴門教育大学)

【目的】最近の 10 年間，発話と手の運動が共通の神経系の 基盤をもち，ヒトの言語活動が手の運動に関する情報処理 に基づいているという。この背景を受けて発話と手の運動 の二重課題の研究が行われた結果, この課題における大脳 半球の非対称性, 発話, 利き手, 注意の関係は多くの論議 の余地を残した。右利きによる二重課題では，手の運動に 与える発話の影響は左手よりも右手の方が顕著であるとい う。光れに対して，この課題の発話に対する影響は右手よ りも左手の方か顕著であるという報告，または年の影響は 左右差がみられないという報告もある。一方，発話と手の 運動が1つの協調構造として結合するという報告もある。 このように，先行研究では注意と利き手に明確な関係が見 られたが，発話と利き手に明確な関係が見出されていない。 したがって，昨年度の発表では右利きの発話と手指のタッ ピングの同時二重課題によって, 利き手と発話の関係に与 える注意の効果を検討した。炎の結果, 発話強調群の右手 は最もタップ間間隔が変動し，2つの運動の非対称な干渉 を示した。本研究ではシンコペーション $(\mathrm{S})$ 課題におけ る発話と手指の運動の相互作用を検討した。S課題とは1 つの運動がもう1つの運動の運動間隔の中間点に位置する ように制御する課題である。同時二重課題よりも，2つの 運動の結合が生じやすい S課題で非対称な干渉と結合/引 き込みがどのように生じるかを検討した。【方法】10名の 右利きの被験者は2つの単一課題と1つのS 課題を行った。 単一課題は右手または左手によるタッピングと発話である

(目標反応間間隔 0.5 秒)。S課題はタップ先行群と発話 先行群に分けられ, 両課題に均等に注意を払つた。 $S$ 課 題の練習中，被験者は0.25秒 (単一課題は 0.5 秒) 間隔の 音刺激にタップと発話 $(/ \mathrm{ba} /-/ \mathrm{ba} /-/ \mathrm{ba} /)$ を交互に同期さ せながら，モニター画面上のタップの目標出力 $2 \mathrm{~N}$ を作る ように教示され，テスト試行では光れを30秒間再生した。

【結果と考察】発話と手指のタッピング開始の差はすべて の条件で0.25秒よりも短かった。発話先行群では発話と タップとの開始の差が 0.05 秒まで短縮されたが，タップ先 行群の光の差は0.13秒であった。このように，発話とタッ プは相互な引き込みを生じた (Treffner and Peter, 2002) が, 発話先行群はタップ先行群よりも強く引き込みを生じ た。Smith et al.(1986)は発話とタッピング運動の同時二 重課題を行った際，発話はタッピング運動に強い影響力を もっていると報告した。発話は発声筋と呼吸筋の出力の制 御を必要とし, 発話と手の運動の引き込みはお光らく呼吸 周期によって引き起こされるという。一方, 発話先行群の $\mathrm{S}$ 課題では, 右手のタップの力が左手の光れよりも変動し たが, 兴の他の条件では右手よりも左手が変動した。また， 単一課題ではタップ間間隔の変動に左右差が見られなかっ たが, タップ先行群の弚れでは右手よりも左手が変動した。 それに対して, 発話先行群のS 課題では右手のタップ間 間隔が左手の光れよりも変動した。このように, 発話先行 群のS課題では右手のタイミングと力の制御が非対称な 干渉を生じた。

Key Word

発話 タッピング シンコペーション
32. 連続的な筋収縮が活動電位の伝播に及ぼす影響：発揮 張力, 組織酸素分圧,筋温との対応関係

○吹上 史康 ${ }^{1}$ 、狩野 豊 $^{1}$

( ${ }^{1}$ 電気通信大学 量子・物質工学専攻 生命情報工学講 座)

【目的】連続的な筋収縮は筋線維膜の機能低下を引き起こ すことが報告されている．しかしながら，これまでに連続 的な筋収縮による活動電位の低下か酸素の需要と供給のバ ランスである組織酸素分圧 $\left(\mathrm{PO}_{2}\right)$ によって制限を受けるか 明らかになっていない，光こで本研究は連続的な筋収縮に よる筋線維膜の機能低下と発揮張力, $\mathrm{PO}_{2}$, 筋温との関連 性を明らかにすることを目的とした．【方法】実験には Wistar 系雄ラットの前脛骨筋 ( TA 筋) を用いた .ペント バルビタールによる麻酔下において, 腓骨神経を介した連 続的な電気刺激 $(3 \sim 6 \mathrm{~V}, 1 \mathrm{~Hz}, 2 \mathrm{~ms})$ を 30 分間負荷した。 その際の活動電位を6チャンネルのアレイ電極によって記 録し，筋線維伝導速度(MFCV)，持続時間(Duration)，振 幅(Amplitude)を算出した.また，同時に発揮トルク， $\mathrm{PO}_{2}$, 筋温を測定した . 酸素分圧の測定は酸素クエンチング法に より行った、【結果と考察】30分間の連続的な筋収縮活動 において MFCV は一定の割合で低下し，最終的には初期 值に対して $15.7 \%$ の低下が生じた . 同樣に刺激開始30分後 にはDuration は31.6\%遅延し，Amplitude は40.8\%低下 した .これらの結果は, 筋線維膜においてイオンの流入に よる脱分極一再分極時間の遅延と活動電位の縮小を意味し ており, 膜の興奮性が低下したことを示している．また， 発揮トルクは刺激終了時までに有意に低下した $(35.0 \%)$. これらの変化に対して $\mathrm{PO}_{2}$ は運動開始後約2.5分間までに 減少するものの $(40.7 \%)$, 約 30 秒の定常状態の後，しだい に増加することが示された．また，筋温に有意な変動は観 察されなかった．本研究では連続的な筋収縮によって細胞 膜興奮性の顕著な低下が示された．光の背景には $\mathrm{Na}^{+}$ $\mathrm{K}{ }^{+}$ポンプ能力の低下, $\mathrm{pH}$ の低下, 細胞外 $\mathrm{K}{ }^{+}$濃度の上 昇などが考えられる．筋温は収縮期間を通して変動は見ら れないことから細胞膜の機能低下には影響しないことが示 唆される． $\mathrm{PO}_{2}$ 動態は刺激3分以降には酸素供給は酸素消 費を上回っていることを示唆しており，酸素供給の不足が 細胞膜の機能維持に必要な ATP 合成を制限する因子と なっていないことが考えられる．したがって，細胞膜興奮 性の機能低下は, 酸素供給が十分な環境下においても生じ ることが示唆された .

Key Word

組織酸素分圧 発揮トルク 活動電位 
33. 重量荷重と受動的体位変換による固有感覚入力の増大 によるヒラメ筋 $\mathrm{H}$ 反射の変化

○江川 賢一 ${ }^{1}$ 、荒尾 孝 ${ }^{2}$ 、種田 行男 ${ }^{3}$ 、北畠 義典 ${ }^{1}$ 、 塩澤 伸一郎 4 、森下 元賀 4

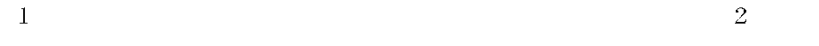
田大学スポーツ科学学術院、蛙京大学生命システム工学部、 ${ }^{4}$ 社会医学技術学院)

【目的】身体不活動に伴う模擬無重力条件においてヒラメ 筋脊骾運動神経の興奮性か増大する (北畠2004)。この作 用機序としては姿勢保持による固有感覚入力の減少に伴い、 シナプス前抑制が減少することが考えられた。光こで本研 究では重量荷重および受動的体位変換による持続的な固有 感覚入力の増大がヒラメ筋 $\mathrm{H}$ 反射に及ぼす影響を検討し た。【方法】事前に同意を得た健常成人 39 名を次の3群に無 作為割付した。重量荷重群：体重の $10 \%$ 相当のリストウェ イトおよびアンクルウェイトを1日あたり累積4時間、5日 間装着する, 体位変換群：電動ベッドにより直立位から仰 臥位 (30秒)，仰臥位から直立位 (30秒) への受動的体位 変換を1セット5回、1日5セッ卜 (約 30 分間)，5日間実施す る,対照群：トレーニングなし。被験者は体位傾斜ベッド 上で直立姿勢を保持し，仰臥位 (SP) , 直立位 (STD) の 順に測定した。ヒラメ筋 $\mathrm{H}$ 反射は膝窩部で脛骨神経を $1 \mathrm{~ms}$ 矩形波パルスで刺激し，トレーニング前後で動員曲線を作 成した。 $\mathrm{H}$ 反射および $\mathrm{M}$ 波振幅は対応する最大 $M$ 波振幅 で標準化した。運動閾值上で誘発した M サイズおよび $\mathrm{H}$ 反射振幅を指標とした。【成績】すべての被験者において 直立時および仰臥位のヒラメ筋および前脛骨筋の背景筋活 動は観察されなかった。M 波の動員曲線パターンおよび $\mathrm{H}$ 波波形はトレーニング前後で変化しなかった。 $\mathrm{M}$ サイ ズはトレーニング前後で有意差か認めなられなかった . 一 方, $\mathrm{H}$ 波振幅はトレーニング前後で仰臥位では減少し， 直立位では変化しなかった，仰臥位から直立位への体位変 換による $\mathrm{H}$ 反射変化率 (STD/SP 比) の平均值は、2つの トレーニング群ではトレーニング前後で増加した。トレー ニング後の $95 \%$ 信頼区間は重量荷重群は0.77-1.11、体位 変換群は0.71-1.03、対照群は0.69-0.93であった。結論】 重量荷重および受動的体位変換による固有感覚入力の増大 を意図した 5 日間のトレーニングは, ヒラメ筋 $\mathrm{H}$ 反射を抑 制し、受動的体位変換に伴う姿勢性調節の作用を相対的に 低下させる可能性が示唆された。【謝辞】本研究は(財)石 本記念デサントスポーツ科学振興財団の助成により行った。
34. 老齢期ラットにおける E ndplate の 3 次元的構造特性

○宮田 浩文 ${ }^{1}$

( ${ }^{1}$ 山口大学 大学院医学系研究科 生物機能科学)

【目的】神経筋接合部を構成する endplate の三次元構築 をもとに形態特性の評価を行い、筋の構造・機能特性との 関連および加齢変化について検討することを目的とした。 【方法】ウイスター系雄ラットの Young (2〜5ヶ月齢、 $\mathrm{n}=5$ ) と moderately old ( 18 22ヶ月齢、 $\mathrm{n}=5)$ のラットを用いた。 3種類の筋（ヒラメ筋、長指伸筋、横隔膜）の筋電図を導 出し、活動量の調査を行った。光の後、麻酔下で各筋を摘 出し、 $4 \%$ パラホルムアルデヒド中にて至適筋長に固定し た後、筋線維上に存在する endplate を、 tetramethylrhodamine $\alpha$-bungarotoxin でラベルした。また、AntiMyosin Heavy Chain を用いて免疫染色 (FITCラベル) を 行った。2Ch (励起波長488nm、543nm)の共焦点レーザー 顕微鏡システム (Nikon, E600 \& C 1) を用いて、 endplate の2次元および3次元構筑・解析 (ソリューションシ ステムズ，3 D doctor）を行った。【結果と考察】以下の4 点が主要な結果であった。1) Old ラットの各筋にワイ ヤ一電極を挿入し、有線で導出した筋電図をもとにDuty cycle (活動時間割合) を算出した。光の結果、横隔膜が 約 $40 \%$ で最も高く、ヒラメ筋が約 $15 \%$ 、長指伸筋が約 $3 \%$ で最も低かった。これらの值は、先行研究で得られた Young における各筋の Duty cycle とほほ等しかった。2) Old ラットの遅筋線維占有率は、ヒラメ筋が約 $90 \%$ で最も 高く、横隔膜が約 $30 \%$ 、長指伸筋が約 $1 \%$ で最も少なかった。 これらの值は、先行研究で得られた Youngにおける各筋 の筋線維組成とほぼ等しく、今回用いたラットが、加齢に 伴う筋の遅筋化が進行する前段階であったことを示唆して (る。3) Old ラットにおいて、3種類の筋上の2次元お よび3次元 endplate 構造特性を比較した結果、エンドプ レートの外周面積・レセプター面積および体積には筋間の 差は認められなかった。4 ) Old 横隔膜のエンドプレー 卜の周囲面積 $(819 \pm 359 \mu \mathrm{m} 2)$ は、Young 横隔膜の值 $(713$ $\pm 189 \mu \mathrm{m} 2$ ) に比べ有意に大きく、空洞率 (周囲面積に対 する空洞面積) は有意に高い値を示した $(45 \pm 13 \%$ vs. 31 $\pm 14 \%)$ 。以上のように、筋線維タイプあるいは活動量 と関連する endplate の形態的指標を見出すことはできな かったが、加齡に伴う endplate の拡大と空洞化が確認さ れた。今回 Old として用いたラットは18２2ヶ月齢であり、 筋線維組成の遅筋化が進行する前段階であることから、 endplate の空洞化は老齢期の筋線維において見られる脱神 経・再神経支配の過程に先行する現象であると考えられる。 今後、2年齢超のラットにおける筋線維タイプ別の形態評 価をすることにより、運動単位における加齢変化のメカニ ズムを明らかにすることが期待される。

Key Word

運動終板 加齢变化 3次元構築 
35. 精密把握課題中の皮質脊髄路の興奮性および皮質内抑制

○遠藤 隆志 ${ }^{1}$, 中島 剛 ${ }^{2}$ 、坂本 将基 ${ }^{3}$ 、田添 歳樹 ${ }^{3}$ 、 米田 継武 1 小宮山 伴与志 ${ }^{3}$

$\left({ }^{1}\right.$ 順天堂大学 スポーツ健康医科学研究所、 ${ }^{2}$ 国立身体障 害者リハビリテーションセンター研究所、 ${ }^{3}$ 東京学芸大学 大学院 連合学校教育学研究科)

これまで経頭蓋的磁気刺激法 (TMS) を用いて、精密 把握運動および強力把握運動時の皮質運動野の興奮性およ び皮質内抑制における課題依存的変化を報告したものは多 い (Datta et al. 1989; Flament et al. 1993; Schieppati et al. 1996; Hasegawa et al. 2001; Tinazzi et al. 2003)。しか しながら、両把握課題間で物体把握の方法が大きく異なる ために共同筋活動および発揮筋力において大きな差が認め られ、課題遂行時の精密さの違いで皮質運動野の興奮性お よび皮質内抑制か変化するかどうかは明らかにされていない。

光こで本研究では、精密さを必要とする精密把握課題に おいて皮質脊髄路の興奮性および皮質内抑制はどのような 修飾を受けるかについて明らかにすることを目的とした。

被験者は健常成人男性8名 $(21 \sim 27$ 歳) であつた。被験 者は物体を普通に第一指と第二指で摘む課題 (NP) およ びNP課題と同じ把握方法で物体を落とさない必要最小限 の把握力で物体を摘む課題 (MS) を行った。MS 課題は、 把握物体を実際に3 5回滑り落とすことにより、把握物体 の重量を学習した後行われた。重量負荷は50、100、200、 $400 お よ ひ ゙ 600 \mathrm{~g}$ の5種類であった。両課題ともに各重量付 加で10回ずつ課題が遂行された。課題遂行中、把握力が安 定したところで経頭蓋的磁気刺激（安静時閾值の1.1 1.2 倍) が被験者の皮質運動野に与えられ、第一背側骨間筋の 表面筋電図より誘発される運動誘発電位 (MEP) の振幅值、 MEP 後に現れる筋電図消失期間 (SP) および背景筋電図 量が解析された。また、課題遂行中の把握力も記録した。

全ての重量負荷において、NP 課題の把握力は MS 課題 の約2倍あり、また背景筋電図量も NP 課題に比して有意 にMS 課題で少なかった（ともに $\mathrm{P}\langle 0.01)$ 。しかしながら、 全ての重量負荷において MEP および SP は両課題間で有 意な差が認められなかった (P) 0.05$)$ 。背景筋電図量で 標準化した MEP および SP は全ての重量負荷において MS 課題でNP課題に比して有意に大きかった（ともに $\mathrm{P}$ $<0.01)$ 。

NPおよび MS 課題間で有意に把握力および背景筋電図 量において有意な差が認められたため、MS 課題では NP 課題に比して精密な運動を遂行していたと考えられる。 MEP の大きさおよびSP の長さは光れぞれ皮質脊髄路の興 奮性、皮質内抑制を示し、これらは背景筋電図量と関係が あることが報告されている（Di Lazzaroet al. 1998; Mathis et al. 1998; Taylor et al. 2002)。ゆえに本研究結 果は、皮質脊髄路の興奮性および皮質内抑制は運動課題の 精密度に依存して変化すること、およびこれらが精密な運 動制御時において重要な役割を果たしている可能性を示唆 する。

Key Word

運動制御 皮質運動野 経頭蓋的磁気刺激
36. バドミントン選手における皮膚反射の可塑的変化

○立松 幹浩 ${ }^{1}$ 、中島 剛 $\left.\right|^{2}$ 、坂本 将基 $^{3}$ 、田添 歳樹 ${ }^{3} 、$ 小宮山 伴与志 ${ }^{4}$

$\left({ }^{1}\right.$ 千葉大学 教育学研究科 保健体育専攻、 ${ }^{2}$ 国立身体障 害者リハビリテーションセンター、 ${ }^{3}$ 東京学芸大学大学院、 ${ }^{4}$ 千葉大学教育学部)

【目的】ヒトで特異的に発達しているつまみや書字などの 手指の円滑な運動や巧みな運動の遂行には体性感覚受容器 からの感覚情報が不可欠であることから (11ic and Ziemann, 2005)、手固有筋では皮膚反射か顕著に発達して いる (Evans et al., 1989)。皮膚反射は痛みを伴わない触、 圧、振動等の外的刺激により誘発され、筋電図上では多相 性の反射効果として出現する。また、各皮膚反射成分は独 立した反射経路を持つことが知られている (Cassia et al. 1973; Jenner and Stephens, 1982; Deuschl et al., 1995; McNulty et al., 1999; Mcnulty and Macefield, 2001)。近年、 皮膚反射は刺激指により反射応答が大きく異なる、“刺激 部位特異性”が存在し、さらにこの特性は遂行する運動課 題によって変化することが報告された (Nakajima et al. 2005)。皮膚反射の刺激部位特異性は、機能的な物体把握 等に貢献している可能性が考えられているが、長期間にわ たる手指のトレーニングが皮膚反射の刺激部位特異性に与 える影響は検討されていない。光こで本研究では，一側上 肢によるラケット操作を長期間に渡って行っているバドミ ントン選手を対象として、皮膚反射の左右差を検討するこ とにより、皮膚反射の可塑的変化について明らかにするこ とを目的とした。【方法】被検者は6年以上バトミントン競 技を継続している成人男女11名 (BD 群：19-41歳) およ び習慣的に運動を行っていない成人男女10名（NM 群： 22-47歳) であった . 運動課題は、最大筋力の $10 \%$ で等尺 性筋収縮による親指 (D1)、人差し指 (D2) および小指 (D5) の外転を左右個別に行わせた。皮膚反射は D1，D2および D5の手掌面を低強度電気刺激 (刺激頻度 $1^{-2} \mathrm{~Hz}$ のランダ 厶刺激，感覚閾值の 2.0 倍， 2 連発、 $3 \mathrm{~ms}$ 間隔) すること により誘発した。筋電図記録は第一背側骨間筋 (FDI)、 母指球筋 (Th) および小指外転筋 (ADM) から双極導出 で記録した。本研究では皮膚反射の中潜時成分 (E2、潜 時約60-90ms) の peak-to-peak 振幅を計測した。【結果】 $\mathrm{BD}$ 群，NM 群ともに刺激部位特異的な反射パターンが確 認された。しかし、BD 群の右 Th に関し、D1、D2刺激 で誘発された E2は、左側ならびに NM 群よりも有意に低 値を示した。考察】本研究で焦点を当てた E2は皮質経由 であると考えられている (Jenner and Stephens, 1982)。 $\mathrm{NM}$ 群では E2に左右差は見られなかった。しかし、経年 的に一側上肢によるラケット操作を特異的にトレーニング している BD 群では NM 群に対して、Thの D1および D2 刺激時の時に利き側の E2が低下していた。これらの結果は、 E2を形成する皮膚反射経路が長期における反復トレーニ ング効果を受けて可塑的に変化した可能性を示唆する。

Key Word

皮膚反射 可塑性 トレーニング 
37. 足底感覚及び下腿筋固有受容覚が立位姿勢制御に及ぼ す影響一足底、下腿個別冷却による比較一

○崎田 正博 ${ }^{1}$ 熊谷 秋三 ${ }^{3}$ 河野 一郎 ${ }^{2} 、$ 高杉 紳一 郎 ${ }^{2}$

( ${ }^{1}$ 麻生リハビリテーション専門学校 理学療法学科、 ${ }^{2} 九$ 州大学病院 リハビリテーション部、 ${ }^{3}$ 九州大学大学院 健康科学センター)

【目的】不意な外乱刺激が身体に加えられた際に即時的に 姿勢を回復させる神経系の作用が知られている。これらの 作用は、足底感覚や筋紡鍾感覚を介していると予想される。 兴のため本研究では、足底メカノレセプターや筋紡錘感覚 神経の入力信号が減少したときに外乱刺激後の筋反応潜時 と重心 (COG)、足圧中心(COP)の偏位にどのような影響が 生じるかを調べ、感覚情報の即時的反応への貢献を検討し た。足底感覚と下腿筋固有受容覚のどちらが立位姿勢制御 に寄与するか、足底と下腿の個別冷却により検討した。方 法】対象は、健常男性12名(年齢: $21.3 \pm 2.9$ 歳、身長: 170.8 $\pm 6.2 \mathrm{~cm}$ 、体重 $65.3 \pm 6.0 \mathrm{~kg}$ )。冷却部位は、足底と下腿(前 脛骨筋, TA 及びヒラメ筋, Sol) の個別冷却とした。冷却後 皮膚温条件は、予備実験結果を基に冷却前(コントロール)、 冷却後3分以内(筋紡錘及び運動神経筋接合部が不活性の設 定)および冷却後皮膚温 $20^{\circ} \mathrm{C}$ 以上(筋紡錘のみ不活性の設 定)とした。外乱方向は、足底板前方移動と後方移動とした。 これら冷却部位 2 条件、冷却後皮膚温 3 条件及び外乱方向 2 条件の COG と COP 初期反応偏位 $(\mathrm{cm})$ と初期反応偏位到 達時間 (ms)、TA (前方移動に対して)と Sol (後方移動に 対して)の筋反応潜時(RT)を抽出した。統計処理は、冷却 部位 2 条件、冷却後皮膚温 3 条件と外乱方向 2 条件で ANO. VAを実施した。【成績】TA と Sol の RT は冷却による影 響はなかった。条件 $\mathrm{A}$ (足底冷却、皮膚温20度以上、足底 板後方移動) において、COG と COP の初期反応偏位到達 時間はコントロールと比較して有意に遅延 ( $\mathrm{COG}, \mathrm{P}$ $\left\langle 0.01\right.$; COP, P $\left\langle 0.01\right.$ ) した。条件 B (下腿冷却、皮膚温 $20^{\circ} \mathrm{C}$ 以上、足底板後方移動) は、コントロールと比較して有意 差はなかった。条件 C (足底冷却、皮膚温 $20^{\circ} \mathrm{C}$ 以上、足底 板前方移動) と条件 D (下腿冷却、皮膚温 $20^{\circ} \mathrm{C}$ 以上、足底 板前方移動) は、コントロールと比較して有意差はみられ なかった。COG と COP の初期反応偏位は冷却による影響 はなかった。【結論】局所冷却による神経伝導速度の影響 はなかったため RT に変化がなかったと思われた。条件 A では、初期反応偏位到達時間がコントロールと比較し有意 に遅延し、逆に条件 B では有意差はみられなかったこと から、身体が前方に動摇した際の姿勢反応には下腿筋固有 受容器からの情報よりも足底メカノレセプターからの情報 が反射性の姿勢回復反応に寄与していると考えられた。条 件 C、Dでは、初期反応偏位到達時間に有意差を認めな かったことから、身体が後方に動摇した際の姿勢反応には 足底メカノレセプターの情報は強く関与しないと示唆された。

Key Word

足底メカノレセプター 筋紡鍾 重心と足圧中心

\section{8．長腓骨筋皮膚反射の部位依存性について}

○中島 剛 ${ }^{1}$ 、遠藤 隆志 ${ }^{2}$ 、坂本 将基 ${ }^{3}$ 、田添 歳樹 ${ }^{3}$ 、 中澤 公孝 ${ }^{1}$ 小宮山 伴与志 ${ }^{4}$

( ${ }^{1}$ 国立リハビリテーションセンター研究所、2 ${ }^{2}$ 順天堂大学、 ${ }^{3}$ 東京学芸大学大学院、 ${ }^{4}$ 千葉大学)

【目的】静的筋収縮時における皮膚反射は、足部の異なつ た支配領域を持つ神経束刺激において神経特異的な反射パ ターンが生じないことが知られている(Komiyama et al., 2000)。しかしながら、我々は、脛骨神経の支配領域であ る足底皮膚の異なる部位を電気刺激することにより皮膚反 射の逆転現象が生じることを報告した (Nakajima et al.， 2006)。例えば、外側前部刺激では、長腓骨筋 (PL) の中 潜時反応は抑制効果であるのに対し、内側前部では促通効 果となる。しかしながら、これらの部位依存的な皮膚反射 の逆転現象の詳細については十分に検討されていない。光 こて健常成人を対象として、同じ足底皮膚の神経 (内側足 底神経) 支配である足底前部内側部 ( $f-M)$ と第一趾

(Toe 1) の皮膚に対する電気刺激によって誘発される PL 皮膚反射が、どのように修飾を受けるのかについて検討し た。【方法】被験者は、神経学的疾患のない健康な成人男 性13名 (22-34歳) であつた。筋電図 (EMG) は長腓骨筋

(PL) から双極導出した。運動課題は足部外返し運動を 行なわせた $(10 \% \mathrm{EMG}$ max $)$ 。電気刺激は足底前部内側 面 $(\mathrm{f}-\mathrm{M})$ 足底前部外側面 $(\mathrm{f}-\mathrm{L})$ 、踵面 $(\mathrm{HL})$ および第1 趾 (Toe 1) に刺激電極を $2 \mathrm{~cm}$ 間隔で貼付し、双極刺激法 により (刺激強度: 感覚閾値の2倍、刺激パルス数: 5 発 $(333$ $\mathrm{Hz})$ をランダム $(0.8-2 \mathrm{~Hz})$ に与えた。実験1（10名の被 験者) では f-M、f-Lおよび HLの PL 皮膚反射における 刺激部位依存性を検討した。さらに実験2 (7名の被験者) では内側足底神経の支配領域である $\mathrm{f}-\mathrm{M}$ と Toelを刺激し、 兴の皮膚反射パターンについて検討した。皮膚反射の誘発 は、EMG 信号を全波整流し、平滑化した後、各指激部位 への電気刺激をトリガーとして80回の加算平均を行なった。 得られた皮膚反射は、中潜時反応 (MLR: 頂点潜時： 70-110 ms）を解析の対象とした。【結果】 $\mathrm{f}-\mathrm{M}$ 刺激時では、 PL 皮膚反射反応は抑制効果を示した。一方、 $\mathrm{f}-\mathrm{L}$ および HL では促通効果を示し、非常に強い刺激部位依存性が確 認された (実験1)。さらにToel刺激では、促通性の皮膚 反射反応が得られた。Toelは、f-M と同じ神経支配領域 であるが、抑制性反応が促通性反応に転じる、いわゆる゙ 皮 膚反射の逆転現象”が観察された (実験2)。【考察】実験 1 での刺激部位として選択した $\mathrm{f}-\mathrm{M} 、 \mathrm{f}-\mathrm{L}$ および HL は、 脛骨神経が足首レベルで分枝する異なる神経の支配領域で ある (f-M: 内側足底神経、 $f-L:$ 外側足底神経、HL: 踵骨 神経)。これらの解剖学的知見をもとにして考えると、足 底神経特異的な反射効果を捉えたものと考えられる。しか しながら反射の逆転現象は、同じ足底皮膚神経の支配領域 においても生じることからも、神経支配領域依存的という よりも部位依存的な反射反応である可能性が高い。この要 因として、各刺激部位において運動ニューロンへの抑制性 および促通性入力のバランスが変化していることが考えら れる(De Serres, 1995)。これらの結果から PLの皮膚反射 経路は部位依存的であり、部位によって关れ独立した 反射経路を持つ可能性が示唆された。

Key Word

皮膚反射 部位依存性 長腓骨筋 


\section{9. 成人と児童の歩行周期の規則性の比較}

○飯田 智行 ${ }^{1}$ 、枝松 千尋 ${ }^{2}$ 、宮川 健 ${ }^{3}$ 、小野寺 昇 $^{3}$ $\left({ }^{1}\right.$ 川崎医療福祉大学 医療技術学研究科健康科学専攻、 ${ }^{2}$ 倉敷芸術科学大学、 3 川崎医療福祉大学)

【背景】加齢とともに歩行速度、歩幅等が減少する。この ことから、歩行速度や歩幅の測定が行われ歩行機能の評価 指標として用いられている。下位中枢機能 (Central Pattern Generator : CPG) は、歩行周期を生成していると考 えられる。歩行は最も基本的な周期運動であるが、光の周 期の時間的変動つまり規則性についてはこれまで評価基準 が示されていない。我々は、歩行周期の規則性を定量化す ることにより、歩行生成に関与する中枢機能の評価が可能 になると考え、時系列データの規則性を評価する Approximate Entropy (ApEn)を用いて、歩行中の頭部動 摇周期の規則性の検討を行っている。現在までに得られた 結果は、歩行周期の規則性の定量化が、姿勢制御を含む歩 行機能を評価する可能性を示している。姿勢制御の機能が 発達段階であると考えられる児童を対象に歩行中の頭部動 摇周期の規則性を測定し、児童と若年成人の違いが歩行中 の頭部動摇周期の規則性に及ぼす影響を検討した。【方法】 若年成人 20 名 $(21.4 \pm 1.3$ 歳) と児童 17 名 (9.0土1.2歳) を対象とした。姿勢制御機能を評価するため重心動摇測定 を行い、外周面積を指標として用いた。歩行周期の規則性 の評価は、対象者に $40 \mathrm{~m}$ の自由歩行を行わせ、頭部左右動 摇加速度を測定し、ApEn を用いて歩行周期の規則性を算 出した。ApEn 值の低值は、規則性が高くなることを示す。 【結果】外周面積は、児童が $3.0 \pm 1.1 \mathrm{~cm}^{2}$ 、若年成人が 1.9 $\pm 0.8 \mathrm{~cm}^{2}$ であり、児童が有意に高值を示した。歩行中の 頭部動摇周期の規則性を示す ApEn 值は、览童が $0.840 \pm$ 0.080 、成人が $0.784 \pm 0.094$ であり、児童が有意に高値を 示した。つまり、児童は、成人と比較して歩行周期の規則 性が低いことが明らかになった。【考察】児童は、頭部が 大きく足底が小さいためバランスのとれた体型をしていな いことや、神経系の機能が発達段階であることから、不安 定な姿勢保持を示すことが明らかにされている。本研究の 対象者の児童においても同樣の結果が得られ、姿勢制御機 能が発達段階であることが示された。児童は、重心動摇距 離に対する頭部動摇距離の比が成人群よりも有意に大きい ことが先行研究により明らかにされている。これらのこと から、児童は、末梢からの感覚フィードバック機能や平衡 能力が若年成人に比べ劣るため、歩行中も不安定な姿勢保 持を示すと推測される。光のため、重心の動摇距離か増加 し、頭部動摇も増加する。 $\mathrm{CPG}$ への情報量が増加し、 $\mathrm{CPG}$ が歩行周期を調整するため、児童の歩行中の頭部動 摇周期の規則性が低下したものと考えられた。以上のこと から、姿勢制御機能が発達段階にある览童は、成人と比較 して歩行中の頭部動摇周期の規則性が低いことが明らかに なった。

Key Word

歩行周期 Approximate Entropy 規則性

\section{0．課題に対する予測がバランス機能に及ぼす影響}

○林 久仁則 ${ }^{1} 、$ 西平 賀昭 ${ }^{1}$ 、衣笠 隆 ${ }^{1}$ 、紙上 敬太 ${ }^{1} 、$ 東浦 拓郎 ${ }^{1}$

( ${ }^{1}$ 筑波大学大学院 人間総合科学研究科)

【背景】我々はEquitest (Neurocom 社)を用いた感覚外乱 下において、スポーツ選手の動的バランスが優れていたこ とから、正確な感覚入力を参照する中枢性の補償作用が運 動習慣により向上するという可能性を報告したが(第14回 運動生理学会, 2006)、床水平外乱刺激に対する身体応答の 潜時に関しては差が見られなかった。先行研究では、立位 姿勢の制御において、足間接まわりの姿勢筇群の準備状態 によって修飾される伸張反射の閾值や利得が変化すること が報告されている(Woollacott M et al. 1993)。姿勢の変動 が予測されると、姿勢筋群の活動水準が変化する (Prochazka A et al. 1989)という報告からも、バランスを 乱す外部要因に対する心的準備や情報といつたものが、随 意的な反応性の調節にも深く結びついている事が明らかで ある。一定の周期で与えられる床振動に対する予測的姿勢 制御の研究や、随意動作に先行した予測性姿勢調節の研究 は数多く報告されているが、一過性の水平床外乱刺激に対 して、弚の内容説明に伴う課題に対する予測が身体応答に どのように反映されるかを示した研究は行われていない。 【目的】課題に対する予測性の変化が、バランス機能にど のような影響を及ぼすのかを検討することを目的とした。 また、従来の静的バランス課題と動的バランス課題との間 に関連性が存在するのかを調査するために、静的バランス を評価する項目についても調査した。方法】男女26名(28.1 \pm 8.8 歳)が実験に参加し、無作為に2群に分けられた。 Equitest を用いて、立位時に外乱刺激を与えた。弚の反応 を以下の点で得点化し、比較した。1)感覚の協調性、2)前 後方向への水平外乱刺激に対する潜時の速さ、3) 5 回反復 される傾斜変動への適応能力。一方の群には課題遂行前に 課題内容を説明し、もう一方の群には内容を伝えず安静立 位状態を保つようにのみ指示する事で課題の予測性を操作 した。また、従来の静的バランス課題と動的バランス課題 との関連性を調査するために、静的バランス課題も実施し た。動的バランスと脚筋力の相関が報告されていることか ら、脚筋力についても溙の伸展/屈曲のピークトルクを計 測した。【結果】静的バランス課題である、両足の開眼/閉 眼立位と、片足開眼立位の重心動摇距離と面積に2群間で 差はなかった。得られたピークトルク値の比較より、脚筋 力にも差か認められなかった。また上記 1$) － 3)$ の得点及び 潜時に関しても統計的な有意差は認められなかった。

【考察】静的バランス能力と脚筋力に差がなかったことか ら、無作為に分けられた2群間の体力的特徵にはほぼ差が なかったことが考えられる。課題に対する予測の有無に関 わらず、動的バランス機能と一過性の水平床外乱刺激に対 する身体応答の潜時には差が認められなかったことから、 課題に対する予測や心的準備が Equitest のバランス機能 評価においては影響を及ぼさない事が示唆された。課題光 のものが未知もしくは未経験であったことから、予測に基 づいた姿勢制御の立て方が困難であつた事が考えられる。 また、言語教示による課題についての説明という点で、予 測性をコントロールするには充分ではなかった事も要因の 一つに考えられた。

Key Word

バランス機能 Equitest 課題の予測 
41．追従性周期運動におけるリズム制御様式の転移

○横井 孝志、淺井 義之 ${ }^{1}$ 、金子 文成 ${ }^{1}$ 、小峰 秀彦 1 菅原 順 $^{1} 、$ 吉澤 睦子 ${ }^{1} 、$ 木塚 朝博 $^{2}$

( ${ }^{1}$ 産業技術総合研究所人間福祉医工学研究部門、2 ${ }^{2}$ 筑波 大学 体育科学系)

ヒトが周期的な運動を行う際には、脳内で生成したリズム に合わせて四肢や全身を周期的に動かす樣式だけでなく、 外界の目標リズム (例えば視覚や聴覚によって認識した周 期的な運動やリズム) に動きを同調させて四肢や全身を動 かす樣式も存在する。前者は生成された周期運動が主に内 的リズムによって制御されるという意味でフィードフォ ワード的制御 (FFC)、後者は外的リズムと内的リズムの 差異を用いて動きを調節するという意味でフィードバック 的制御 (FBC) と位置づけられる。一方、これらの制御樣 式はリズムの周期に依存して選択され、周期が短いほど FFC が、周期が長いほど FBC が優位に働くと言われてい る。このことは、運動周期の増加あるいは減少の過程で、 2つの制御樣態の優位性が入れ替わることを示唆する。 本研究では、周期的に動く視覚的目標に合わせて立位身体 (足圧中心位置：COP) を左右に動かす課題を用いて、樣々 な周期による目標のリズムと光れに合わせた身体の周期運 動制御の樣式との関連性を検討し、立位周期運動時のリズ 么制御樣式転移の樣態を明らかにする。成人男性被験者 13 名に、立位状態の被験者の前方 $3.8 \mathrm{~m}$ に置いたスクリーン 上に左右に周期振動する C O P目標および被験者のC O P を提示し、目標をできるだけ正確に追従するように指示し た視覚目標周期は $30.0,20.0,10.0,5.0,4.0,3.0,2.5$ ， $2.0,1.5,1.0,0.8,0.5,0.4$ 秒であった。相関関係の定 性的把握: 目標 COP 波形と出力 COP 波形との間の相関関 係、位相差を求め、これらをもとに上記課題を検討した。 位相差の平均と標準偏差の傾向を考慮すると、リズム周期 が30秒から2秒に近づくにつれてリズム運動を修正・調節 する要因が外的なもの (FBC) から内的なもの (FFC) に 徐々に変化し、周期が $0.8 \sim 2$ 秒 (周波数が $0.5 \sim 1.25 \mathrm{~Hz}$ ) の範囲では主に脳内で生成した目標リズムに従って周期運 動追従が行われている可能性がある。 $2 \mathrm{~Hz}$ 以上の周波数 (周 期0.5秒以下) では、身体の慣性やリズム切り替えの限界 のため、安定したリズムの生成か難しくなったと考えられ る。

Key Word フィードバック制御 フィードフォワード制御 立位周期 運動

\section{2. 筋内電気信号の多チャンネル解析}

○水村 信二 1 、大筑 立志 $^{2}$ 、前澤 克彦 3

( ${ }^{1}$ 明治大学 文学部、 ${ }^{2}$ 東京大学大学院 総合文化研究科、 3順天堂大学 医学部 整形外科学講座)

【緒言】これまで、ヒトの随意的力発揮時における運動単 位発射樣式に関する研究の多くは、低強度あるいは中程度 のカレベルにおける力発揮時に記録された 1 チャンネルの 筋内電気信号を解析したものといえる。著者らはこれまで、 短時間（10 秒以内）における中一高強度（随意最大収縮 レベル, $100 \% \mathrm{MVC})$ の等尺性力発揮時における内側広筋の 運動単位発射樣式を、3 チャンネル同時解析手法 (Precision decomposition, De Luca 1993) を用いていく つかの報告を行ってきた。本研究では、長時間にわたって 運動単位発射活動を正確に解析することが出来るかどうか を確かめるため、低強度て持続的な力発揮時の筋内電気信 号を 2 チャンネル同時記録し、2 チャンネル同時解析手法 を用いて運動単位発射活動を解析した。【方法】被験者は、 健常成人男性 4 名 ( 2 2 - 42 歳) であった。被験者は、 実験用椅子に座り、右膝を 90 度屈曲位にて固定され、右 膝伸展方向の等尺性台形状力発揮課題を遂行した。台形状 力発揮課題は、力漸増相 $(5 \sim 10 \% \mathrm{MVC} /$ 秒 $)$ 、力保持相 (10\%MVC、10 - 240 秒) および力漸減相 $(-5$ $-10 \% \mathrm{MVC} /$ 秒) からなり、1〜2秒かけて $10 \% \mathrm{MVC}$ まで力 を漸増し、光の後 10 ２40秒間兴の力を保持し、再び1〜2 秒かけて0\%MVC まで力を漸減するものであった。この際 の力信号、表面筋電気信号および2 組の筋内電気信号を同 時記録した。2 組の筋内電気信号は、四極ワイヤー電極

(Mizumura 1999、ユニークメディカル社) を用いて、電 位検出ベクトルの異なるものを導出され、Spike2ソフト ウエア (CED 社)の 2 チャンネル解析モードを用いて、個々 の運動単位活動電位発射列入と分離分解し、動員閾値張力 と発射頻度との関係について観察した。【結果】多くの試 行において、複数の運動単位を同定することができた。複 数の運動単位が同定された全ての試行において、動員閾値 張力の低い運動単位は、動員閾値張力の高い運動単位より も、平均発射頻度が高かった (Onion skin 現象, Erim et al. 1996)。【論議】本研究では、チャンネル解析法を用い ることによって、最長 4 分間の低強度て持続的な力保持時 における筋内電気信号を、個々の運動単位活動電位へと正 確に分離分解することができた。また、随意等尺性収縮に おける運動単位発射樣式の特性として知られている Onion skin 現象は、動員閾値張力が $3 \% \mathrm{MVC}$ 前後の低值で、しか も動員閾値張力の差が $0.2 \% \mathrm{MVC}$ というきわめて小差の 場合においても認められることが明らかとなった。文献】 De Luca C. J. (1993). Methods in Clinical Neurophysiolo. gy, 4, 1-28. Erim Z. et al. (1996). Muscle \& Nerve, 19, $563-573$.

Key Word 運動単位 多チャンネル解析 四極ワイヤー電極 


\section{3. 静的筋収縮時の負荷形式による運動持続時間の違い}

$\bigcirc$ 桐本 光 $^{1}$ 、後藤 純信 $^{1}$ 北田 耕司 $^{2}$ 、與谷 謙吾 $^{3} 、$ 田巻 弘之 ${ }^{3}$

( ${ }^{1}$ 国際医療福祉大学 リハビリテーション学部 作業療法 学科、2 石川工業高等専門学校、 ${ }^{3}$ 鹿屋体育大学)

【目的】静的筋収縮時の負荷形式には，一定の外力を加え られ，これに抗して所定の関節角度を保持する課題

(Position task: PcT) と，関節角度は固定された状態で上 記外力と同じ筋力を保持する課題(Force task: FcT)がある. 本研究では, 静的筋収縮時の負荷形式の違いが運動持続時 間に及ぼす影響について検討した。【方法】健常な成人男 子 8 名が示指外転位 $10^{\circ}$ で最大随意筋力 (Maximal voluntary contraction: MVC) の30\%を保持する第一背側骨間筋

(First dorsal interossei: FDI) の静的筋収縮を，PcTと FcTで光れ光れ疲労困䣏まで行った．被験者は PcT では， $30 \% \mathrm{MVC}$ の錘に抗し，ゴニオメータからのフィードバッ クを受けて示指外転位 $10^{\circ}$ を保持した．Fetでは，ステン ワイヤーで示指外転位 $10^{\circ}$ に固定され，ロードセルからの フィードバックを受けて $30 \% \mathrm{MVC}$ の筋力を保持した . 関 節角度，筋力ともに目標値を $10 \%$ 下回り，3秒経過した時 点を疲労困䣏とした．持続筋収縮に先立ち，20，40，60， $80 \%$ MVC 強度の FDI の静的笳収縮を PcT, FcTで光れ ぞれ10秒間行った. 運動前後には MVC 測定, 及び尺骨神 経への経皮電気刺激による FDI の最大 M 波 (Mmax) の 記録を行った.ゴム枠銀一塩化銀双極誘導電極 (直径 $8 \mathrm{~mm}$ ) を使用し，記録電極をFDI の筋央に，基準電極を第 2 指 中手指節間関節に貼付し，最大筋力発揮時，静的筋収縮持 続中，及び尺骨神経刺激時の筋活動を記録した（通過帯域 $10-2,000 \mathrm{H} \mathrm{z}$, サンプリング周波数 $2,000 \mathrm{~Hz}$ ). 筋力は実 験装置に固定された引張型ロードセル(TEAC, TT-SR)で 検出した . 汎用パーソナルコンピュータに取り込まれた電 気信号は解析ソフト (BIMUTUS 2) を用いて解析処理を 行った . 筋活動レベルは , 全波整流した記録波形の平均振 幅 (meanEMG:mEMG) を用いて定量化した。mEMGは MVC 発揮時の值をもとに正規化した .【結果】10秒間の静 的筋収縮では，両タスクにおける同じ運動負荷強度での筋 活動レベルは等しく，運動負荷強度の増大に伴う筋活動レ ベルの上昇でも，両タスク同樣の直線性を示した．運動持 続時間は FcTが808.5 土421.2秒，PcTが378.2秒土248.3 秒と FcT が有意に長かった $(\mathrm{p}<0.01)$. 筋活動レベルは 両タスクとも運動開始時が $30 \% E M G @ M V C$, 運動終了時 が40\%EMG @MVCで, 運動持続時間が短い F C T で高い上 昇率を示した . 運動前後の最大筋力の低下率は F c T が $39.5 \%$, PcT が $14.9 \%$ と，FcT が有意に大きかった ( p $\langle 0.01)$. 運動後の Mmax は, 運動前と比較して両タスク とも同樣の (約 $30 \%)$ 低下が認められた.【考察】両タス クで運動前後のMmax の低下率が同等で，MVCの低下率 はF F T が高いことから, 運動終了時の末梢疲労のレベル にタスク間の差はないが, 中枢疲労のレベルは運動持続時 間の長い F cT で高いことが考えられる . 運動持続時間が PcTで短い要因は，末梢での疲労が早く進行することだけ でなく，FcTとPCTでは上位中枢における運動制御樣式 にも違いがあることが推察された .

Key Word 筋電図 静的筋収縮 運動持続時間
44. 随意筋収縮時の“筋音( myo-mechanical signal)” の波形特性

○森本 茂 ${ }^{1}$

( ${ }^{1}$ 横浜国立大学 教育人間科学部)

本報告では、ヒトの随意筋収縮中において myoelectrical signal (MES), myomechanical signal (MMS) および tension development の発現順序を以下の観点から特定するこ とを目的とした。(1) 持続的筋力発揮時 (Prolonged Isometric Constant Contraction: PICC) に MMS 積分值が疲 労誘発性振戦 (fatigue induced tension tremor: FIT) の発 現に伴って増大するが、MMS 増大が FIT に伴う皮膚、 皮下組織などの振動に起因する artificial な現象であるか 検討、(2) MES と tension 間の interface としての筋線維 の変異を MMS から検討することの可能性 (tension と筋 線維 (群) の変位一振動、 lateral movement一の関係性)。 方法健康成人男性 (2名) 実験台上に股関節角度・膝関節 角度 90 度で机座位姿勢にて等尺性に膝関節伸展を行った。 このとき、右内側広筋から、MMS（コンデンサー型マイ クロフォン $\phi 10 \mathrm{~mm})$ と $\mathrm{MES}(\mathrm{Ag} / \mathrm{AgCl}$ wire 電極 $\phi 1$ $\mathrm{mm}$ と disk 電極 $\phi 5 \mathrm{~mm})$ を筋線維走行方向に沿った $2 / 4$ 箇所 (運動終板上、光の末梢側) から導出した。被験者に は20\% MVCの目標筋力を、筋力振戦が約 $\pm 1 \% \mathrm{MVC}$ まで、一定保持する課題を設定した。モニター用ブラウン 管上に目標筋力、発揮筋力を表示した。結果と考察 1 . PICC 時に発現した疲労性筋力振戦中、MMSと TF は MES の周波数構成に比較し低い周波数構成にあり、6 $\mathrm{Hz}$ 付近に共通したピークが観察された。また、TFと MMS との相互相関関係において、TF vs. MMS end-plate で30 ms、TF vs. MMS distal で $35 \mathrm{~ms}$ の遅延時間を持って0.5 以上の高い相関係数を示した。この結果は、MMS は TF に先行して発現していることを示している。2. MES と MMS 及び TF 間での発現順序を検討するため、運動終板 上からの MES をトリガー信号とし MMS, TF 加算平均波 形を求めた。加算平均波形から、MES は MMSの発現に 先行し、MMSはTF に先行して発現していることが観察 された。すなわち、3現象の発現には、MES - MMS TF の順序性があった。3. 随意的に単収縮樣の収縮を 行った時、同樣に MES, MMS, tension の発現順序を観察 したとき、振戦時に求められた同樣の順序性が得られた。 以上の結果は、PICC 時の MMS 積分値の増大は、筋力振 戦に起因する皮膚、皮下組織などの振動に原因するのでは なく、筋実質の変異・振動の増大によるものであることが 示唆された。電気信号発生から筋力発現までの間に筋線維 の変位が存在し、 interface として特徵を MMSからとら える可能性が示唆された。

Key Word

筇電位信号 筋振動信号 波形特性 
45. ヒラメ筋 $\propto$ 運動ニューロンに発現するオレキシン 1 型 受容体の特徵

○楯岡 卓 ${ }^{1}$ 、征矢 英昭 ${ }^{1}$

( ${ }^{1}$ 筑波大学大学院 人間総合科学研究科)

【背景】睡眠-覚醒、摂食、ストレス応答、自律神経活動 の調節、ホルモン分泌の調節など多彩な生理機能に関与す る視床下部オレキシン神経は、広範な投射を通じて脳全体 に作用する。关の投射の一部は脳幹や脊䯣を下行して腰髄 前角に入力していることが報告されている。オレキシン神 経の機能を欠損した動物はナルコレプシーという病態を示 し、光の病態の主徵としてカタプレキシー (情動性脱力発 作 : 恐怖、不安、喜びなどの情動的に強い刺激のストレス が加わったときに全身性に起こり姿勢を崩壤する脱力発 作) が見られるため、脊髄への投射は、お光らく $\alpha$ 運動 ニューロンを介した下腿骨格筋の発揮張力調節を担ってい る可能性が考えられた。さらに最近、脊髄腰部前角にオレ キシン A (OX-A) を局所投与すると、下肢骨格筋を支配 する運動ニューロンの興奮閾值が低下し、 $\alpha$ 運動ニューロ ンの発火促進を修飾している可能性が示された。また、脊 骾頸部前角に OX-A を投与すると、横隔膜の収縮張力が 増大したことが報告された。光こで、「体重支持を担うヒ ラメ筋を支配する $\alpha$ 運動ニューロン上には $\mathrm{OX}-1 \mathrm{R}$ が発現 し、オレキシン神経は兴の受容体を介して、ヒラメ筋の収 縮活動を調節しているのではないか」と仮説を立て、これ を検証することを目的とした。

【方法】成熟雄性 Wistar 系ラット5匹の右ヒラメ筋に、逆 行性トレーサーFluoro-Gold を単回投与した。5日後、ペ ントバルビタール麻酔下で断頭し、脊髄腰骾膨大部を摘出 し、コンパウンドに包埋して液体室素で泠やしたイソペン タンで涷結した。脊髄はクリオスタットで連続縦断切片を 作成し、ポリリシンコートスライドグラスに張りつけ、 $4 \%$ PFA で固定後、免疫染色を施した。脊髄の画像は蛍光顕 微鏡で観察し、切片画像をパソコン上に取り込んだ。 Fluoro-Gold 陽性細胞をヒラメ筋 $\alpha$ 運動ニューロンとし、 弚のニューロンの中で OX-1R タンパク発現を有する割合 を求め、乥れを発現率とした。

【結果と考察】逆行性トレーサーの Fluoro-Goldにより、 ヒラメ筋を支配する $\alpha$ 運動ニューロンを同定した。同定さ れた $\alpha$ 運動ニューロンのほとんどに OX-1R が発現してい ることがはじめて明らかになった。この結果から、視床下 部オレキシン神経が体重支持を担うヒラメ筋を支配する $\alpha$ 運動ニューロンを直接支配し、 $\alpha$ 運動ニューロンの活動を 調節している可能性が示された。情動的ストレスが加わっ たときに、視床下部オレキシン神経は $\alpha$ 運動ニューロンに 発現する OX-1R に作用して、姿勢筋の持続的な収縮活動 の促進または維持に関与しているのかもしれない。

Key Word

オレキシン ヒラメ筋 $\alpha$ 運動ニューロン
46. 片脚サスペンジョン中のインターバルトレーニングが 筋機能・形態に及ぼす影響

○秋間 広 ${ }^{1}$ 、堀田 典生 ${ }^{2} 、$ 佐藤 耕平 $^{3}$ 、石田 浩司 ${ }^{1}$ 、 片山 敬章 1 、小池 晃彦 ${ }^{1}$

( ${ }^{1}$ 名古屋大学総合保健体育科学センター、年名古屋大学大 学院、㫜本女子体育大学)

はじめに 宇宙飛行士による国際宇宙ステーションでの滞 在や一般人による宇宙観光旅行, さらに近未来に計画され ている月基地の建設や火星探査等により，人類が宇宙空間 に飛び立つ機会は今後ますます増えることが予想される． 产の最前線で重要な任務を行うのは宇宙飛行士であるが， 長期宇宙滞在が始まった現在においても，微少重力環境が もたらす身体機能低下に対する運動処方は未だ確立されて いないのか現状である. 本研究では片脚サスペンジョンと いう比較的新しい擬似宇宙滞在モデルを用いて，20日間の 片脚サスペンジョン中のインターバルトレーニングが筋機 能と筋形態に及ぼす影響について検討した . 方法成人男性 11名が実験に参加し，片脚サスペンジョン中にトレーニン グをする群 (6名) と片脚サスペンジョンのみの群 (5名) に分けた . 片脚サスペンジョンは実験脚の体重支持活動と 筋活動を限りなく少なくするモデルである . トレーニング は自転車エルゴメーターを用いた実験脚での自転車運動で， 最高酸素摂取量の $40 \%$ ～ $80 \%$ の運動負荷を計 25 分間行うイ ンターバルトレーニングであった .トレーニングは 20 日間 の実験期間中に10回行った . 膝伸展による随意最大筋力 , MRI による大腿部の筋体積，骨格筋 fMRI による筋機能を 実験脚と非実験脚について測定した . 結果と考察実験脚の 随意最大膝伸展筋力においては, コントロール群で有意に 低下した (548 N から $444 \mathrm{~N} ; \mathrm{P}\langle 0.05,-18 \%)$ がトレーニ ング群では有意な変化は見られなかった $(535 \mathrm{~N}$ から 460 $\mathrm{N},-11 \%)$. 大腿部の筋体積についてはトレーニング群の 実験脚では, 有意な筋体積の変化は認められなかったが， コントロール群では大腿四頭筋，ハムストリング，内転筋 群光れ攵れにおいて-7\%, $-2 \%,-6 \%$ 有意な低下（全て $\mathrm{P}<0.05)$ が認められた.一方, 非実験脚ではいずれも 有意な変化は認められなかった . 最大下での動的膝伸展中 の骨格筋 fMRI については, トレーニング群では両脚に運 動後のシグナル変化に有意な差は認められなかったが , コ ントロール群の非実験脚では運動後のシグナル変化が実験 前の光れと比較して有意に増加した $(38.2 \mathrm{msec}$ から 40.7 $\mathrm{msec})$. 以上の結果から，本研究で用いたトレーニングは， 不活動中の筋機能の維持および筋萎縮の軽減を可能にする 運動プログラムであることが示された . 今後はトレーニン グ効果が得られる最小のトレーニング頻度と最短のトレー ニング時間の模索を行い，長期宇宙滞在中の宇宙飛行士の 運動処方として提案していきたいと考えている .

Key Word

宇宙滞在 筋萎縮 運動プログラム 